Canadian Journal of Fisheries and Aquatic Sciences

Canadian Science Publishing

Journal canadien des sciences halieutiques et aquatiques

\title{
Simulating future climate impacts on tropical fisheries: are contemporary spatial fishery management strategies sufficient?
}

\begin{tabular}{|r|l|}
\hline Journal: & Canadian Journal of Fisheries and Aquatic Sciences \\
\hline Manuscript ID & cjfas-2016-0200.R1 \\
\hline Manuscript Type: & Article \\
\hline Complete List of Authors: & $\begin{array}{l}\text { Kapur, Maia; University of Hawai'i at Manoa, Hawaii Institute of Marine } \\
\text { Biology } \\
\text { Franklin, Erik; University of Hawai'i at Manoa, School of Ocean and Earth } \\
\text { Science and Technology }\end{array}$ \\
\hline Keyword: & $\begin{array}{l}\text { MODELS < General, CORAL REEFS < Environment/Habitat, MARINE } \\
\text { FISHERIES < General, MARINE PROTECTED AREAS < Environment/Habitat, } \\
\text { LAND USE < General }\end{array}$ \\
\hline \multicolumn{2}{|c}{} \\
\hline
\end{tabular}

SCHOLARONE ${ }^{1 m}$

Manuscripts 


\title{
Simulating future climate impacts on tropical fisheries: are contemporary spatial fishery management strategies sufficient?
}

\author{
${ }^{1}$ Maia R. Kapur, ${ }^{1}$ Erik C. Franklin \\ ${ }^{1}$ Hawaii Institute of Marine Biology, School of Ocean and Earth Science and Technology, \\ University of Hawaii at Manoa, Honolulu, HI, 96744, USA \\ Corresponding author: Maia Kapur (maia.kapur@noaa.gov).
}

\section{Abstract}

We demonstrated a possible future wherein coral reefs shift to an algae-dominated state that retains low coral cover and a functional biomass of herbivorous fishes that sustains a reef fish fishery. We evaluate the effect of no-take MPAs and increased coastal nutrients under two IPCC climate scenarios for years 2000-2100, which are implemented as coral bleaching events. Coral mortality from bleaching events drove a lagged increase in herbivorous fish populations, via a shift from coral-dominated to algae-dominated habitats. Biomass and catch of piscivorous fish declined significantly with the fishery shifting to the harvest of herbivorous fish. No-take MPAs for $20 \%$ of reef areas represented a threshold that had a positive effect on herbivorous fishes but no influence on the steep declines of corals and piscivorous fishes. Contemporary no-take MPAs protect less than $1 \%$ of coral reef areas around the Hawaiian Islands; significant management action would be required to approach the $20 \%$ area threshold. 
Coral reefs are globally in decline, with trajectories further threatened by diseases, pollution, coral bleaching, unsustainable fishing practices, and ocean acidification (Miller et al. 2009; Selig et al. 2010; De'ath et al. 2012). A major challenge to marine decision-making is deciphering the contribution of complex ecosystem dynamics to environmental outcomes across broad geographic scales. Agencies tasked with managing reef ecosystems benefit from decisionsupport tools that can estimate changes to coral and fish populations in their region. Ideally, such models incorporate a broad set of biotic and environmental data, and enable managers to "test" fishery management scenarios against changes in ocean chemistry, storm events and temperature. The need to evaluate fishery dynamics in complex ecosystem settings has led to the development and use of ecosystem end-to-end models for coral reef ecosystems (Ainsworth et al. 2008; J. Melbourne-Thomas et al. 2011; Weijerman et al. 2013). A predictive, decision-support model should include a broad set of ecological, and climactic factors unique to the system of interest while the incorporation of spatial dynamics addresses the potential for testing fishery management strategies amidst climate change effects (Rogers et al. 2015).

While negative anthropogenic impacts are severe in many coral reef ecosystems worldwide, the condition of Hawaiian coral reefs has been relatively stable in recent decades (Dollar \& Grigg 2004; Walsh et al. 2013; Rodgers et al. 2015), with the effects of environmental factors driving broad-scale patterns in coral community structure. However, prior studies have limited their focus to impacts on a few ecosystem components (i.e., coral species), and a limited set of environmental stressors such as seawater temperature and acidification (Buddemeier et al. 2011; Hoeke et al. 2011). While the Hawaiian reef ecosystem has demonstrated recent stability at a regional scale, this does not negate the importance of examining reef dynamics to identify potential sensitivities for reef trajectories in the future decades, especially with a recent coral 
47 bleaching event indicating a possible imminent increase in climate-related effects on Hawaiian 48 reefs (Bahr et al. 2015).

Three prominent threats to Hawaiian coral reefs are coral bleaching (Hoegh-Guldberg

50

51

52

1999; Rodgers et al. 2010), nutrients and pollutants from terrestrial sources (Layman et al. 2011; Most 2012), and unsustainable fishing practices (Friedlander et al. 2007). The effects of climate change are expected to increase the prevalence and intensity of degree-heating weeks (DHW), which describe a time period when sea surface temperatures persistently exceed a temperature threshold that can lead to coral mortality from bleaching (Van Hooidonk et al. 2014). The decline of coral populations can lead to a shift to an algal-dominated benthic environment (McManus \& Polsenberg 2004; Ainsworth \& Mumby 2015). While humans cannot control the frequency and intensity of bleaching events, nor completely divert terrestrial input from entering the marine environment, such impacts can theoretically be modulated by fishing activities that change top-down controls upon the affected benthos (Ware et al. 1996; Russ et al. 2015). As herbivory acts as a natural control of algal overgrowth, appropriate management of the trophic structure and grazing biomass upon a reef may curtail degradation following a bleaching event (Mumby 2006; Paddack et al. 2006). In recognition of the important role that herbivores serve on reefs, the Kahekili Herbivore Fisheries Management Area was established on Maui in 2009 to protect herbivorous fish and urchin populations (Williams et al. 2016); contemporary spatial fishery management protects under $1 \%$ of coral reef areas in no-take MPAs in the Hawaiian Islands, with approximately $10 \%$ of reef areas in partially protected MPAs (Friedlander et al. 2003; Friedlander et al. 2008). A scenario-based, decision-support tool that incorporates climate change and human activities provides an ability to test and identify effective spatial fishery management strategies for the Hawaiian region for current and potential future conditions. 
This study develops, validates, and characterizes the sensitivity of a new instantiation of the Coral Reef Scenario Evaluation Tool (CORSET) to the Hawaiian Islands, a chain of eight islands in the central North Pacific Ocean. CORSET was developed as a portable framework to address biophysical processes on coral reefs across multiple spatial scales (Jessica MelbourneThomas et al. 2011). The tool is implemented in the open-source object-oriented Python Programming Language version 2.5 (Python Software Foundation 2011). While originally parameterized for applications on Indo-Pacific and Meso-American reefs, CORSET is readily adaptable to perform scenario testing for the Hawaiian Islands reefs.

The objectives of this study were to provide the first demonstration of the model's portability to a region outside of Meso-America and the South China Sea, and to test and evaluate several spatial management strategies for Hawaiian coral reef fish fisheries with reefs experiencing coral bleaching and elevated nutrient inputs under future climate scenarios.

\section{Methods}

\section{CORSET Structure}

The CORSET model was comprised of four components: local ecology, larval connectivity, and anthropogenic and environmental forcings (Fig. 1). CORSET used a 'functional group' approach to model interactions between benthic functional groups that include two types of corals (brooding and broadcast spawning species) and three types of algae (macroalgae, turf algae, and crustose coralline algae) and consumer functional groups that include herbivorous fish, small-to-intermediate $(<60 \mathrm{~cm})$ piscivorous and large $(\geq 60 \mathrm{~cm})$ piscivorous fish and sea urchins. Turf algae, which is termed 'macroturf' in CORSET's original documentation, refers to algal turfs with height greater than $2-4 \mathrm{~mm}$. Parameters that describe 
local-scale ecological processes were selected at random from predefined, uniform ranges derived from empirical observations. The local-scale ecological model used in CORSET was a mean-field model that describes average interactions between benthic and consumer functional groups, which were coupled across subregions by larval dispersal determined from static connectivity matrices. This structure rendered CORSET as stochastic, with the inclusion of natural disturbances such as bleaching events and direct human impacts (nutrification and fishing). The model includes the possibility of additional forcing functions but we limited the disturbances in this study to bleaching events, nutrification, and fishing. A summary of implementations for human, environmental and physical forcings is found in Table S1.

\section{Model Development and Validation}

We developed a gridded basemap (Fig. 2A,B) consisting of four subregions: 1) Kauai and Niihau; 2) Oahu, 3) Maui Nui (i.e., the islands of Molokai, Lanai, Maui, and Kahoolawe), and 4) Hawaii, also known as the Big Island. The spatial extent of the study domain was $3,263,632 \mathrm{~km}^{2}$ with a total reef area of 1,342 $\mathrm{km}^{2}$ for reefs from 0-30 m depth. Geographically-designated subregions are ideal for organizing management efforts; there is additional genetic evidence that suggests these regions represent shared genetic population breaks (Eble et al. 2011; Toonen et al. 2011). The domain was represented in two resolutions: $2 \mathrm{~km} \times 2 \mathrm{~km}$, and $4 \mathrm{~km} \times 4 \mathrm{~km}$. The $4 \mathrm{~km}$ $\mathrm{x} 4 \mathrm{~km}$ resolution was used for the all validation and sensitivity procedures. A detailed exploration of equilibrium behavior and parameter sensitivities for both the local-scale, differential (continuous) system from which CORSET was derived, and the discrete-time equation array that constitutes the model used here, are each available in the Appendix. We performed a model validation to test whether the calibrated model was able to produce stable long-term (100-year) trajectories in the absence of external forcings, and to 
118

119

120

examine accuracy of the model at matching observed community composition measures for the period from 1965 through 2010. For both procedures, we used initial values for benthic and consumer percent cover and biomass derived from empirical observations wherever possible.

To test whether the model could accurately reproduce observed values for current community composition when provided real world events, we used a range of proportional mortality values from historical bleaching events within the Main Hawaiian Islands (i.e, 5-15\%) with the percentage indicating the proportional loss of coral cover attributable to a bleaching event alone (Hoeke et al. 2011; De'ath et al. 2012; Osborne et al. 2011). We validated the model using real-world bleaching events from the last five decades using this mortality range, which affected the entire MHI in 1996, 2014, and 2015.

Best estimates for historical and current fishing pressure were incorporated into model runs across all functional groups. For validation procedures, present-day fishing catch was made accessible by the State of Hawai'i Department of Aquatic Resources, in tabular and spatial form. The data from 2003 - 2011 were subset for coastal ( $<2 \mathrm{~nm}$ from shore) fishing polygons, from which a fishing pressure parameter $\left(\mathrm{kg} \mathrm{km}^{-2} \mathrm{yr}^{-1}\right)$ was calculated for each subregion (see Appendix). Historical commercial and recreational catch was estimated from prior reports (Pooley 1993). For future scenarios, we modeled fishing pressure as a direct decrease in fish biomass, apportioned between herbivorous, small-to-intermediate and large piscivorous fish groups which updated at each annual interval independently within each reef cell. Fishing pressure values were randomly selected from a uniform distribution of range $0-5000 \mathrm{~kg} / \mathrm{km}^{2} / \mathrm{yr}$. In all sensitivity analyses, fishing pressure was assigned a value of zero throughout the model run. Methods and results for the sensitivity analysis can be found in the Supplementary Material. 
140

141

142

143

144

145

146

147

148

149

150

151

152

153

154

155

156

157

158

159

160

161

162

163

\section{Scenario Sweep}

Table S4 depicts the complement of forcing options selected to test the interaction between spatial fishing closures of different proportions, the frequency and intensity of coral bleaching events, and simulated nutrification events constructed to test potential reef futures under various conditions.

\section{Simulated no-take MPAs}

We used a random number generator to select $5 \%, 10 \%$, and $20 \%$ of coastal reef cells that were modeled as no-take MPAs; reef cells designated as no-take MPAs are excluded from fishing take. While non-contiguous no-take MPA designation is less realistic as a management strategy, CORSET does not model 'spillover' effects between adjacent cells, which would justify testing the effect of various aggregations of no-take regions. Furthermore, the model grid resolution is quite large ( $2 \mathrm{~km} \times 2 \mathrm{~km}$ or $4 \mathrm{~km} \times 4 \mathrm{~km})$ compared to the extent of actual no-take MPAs so a single reef cell may adequate represent the extent of most no-take MPAs. We executed the no-take MPA simulation for both RCP 4.5 (Fig. S7) and 8.5 (Fig 4); RCP 8.5 with $0 \%$ MPAs was the baseline strategy used for comparison against all other scenarios throughout this study.

\section{Simulated Bleaching Events}

To model changes in the frequency and intensity of coral bleaching, we evaluated a suite of management strategies in the context of two Representative Concentration Pathways (RCPs): 4.5 and 8.5 (van Vuuren et al. 2011). The former represents a mitigation regime, wherein carbon emissions result in a mean global temperature increase of $1.4^{\circ} \mathrm{C}$. The latter represents a high emissions regime; it is a so-called baseline scenario in that it does not include any specific climate mitigation target (Riahi et al. 2011). Using the coral bleaching visualization tool for 
164

165

166

167

168

169

170

171

172

173

174

175

176

177

178

Google Earth (Van Hooidonk et al. 2014), we have identified spatial and temporal projections of where degree-heating weeks (DHWs) exceed 8 per annum. We interpret such an event as a "bleaching event", e.g. under RCP 4.5, it is projected that the MHI will experience, on average, two DHW $>8$ events per decade through the year 2056, after which it will undergo DHW $>8$ annually. Under RCP 8.5, bleaching occurs with a long-term frequency of twice per decade until year 2046, after which it occurs annually; in all cases, mortality ranges from $0.05-0.15$.

\section{Simulated nutrification}

Nutrification was modeled during the scenario sweep in a similar manner to fishing closures; At each of $5 \%, 10 \%$, and $20 \%$ proportion of reef cells were designated as "affected by nutrification". This designation converts the range of scaling factors for turf algae growth rate to $2-7$ and coral larval production to $0.75-1.0$. We examined RCP 8.5 scenarios wherein nutrification was forced alone and alongside the presence, in equal proportion, of MPA closures. In these cases, cells were selected at random.

\section{Results}

\section{Model Validation}

In the absence of forcings, CORSET exhibited steady-state behavior for all variables after $\sim 30$ years (Fig. 3). Compared to historical values for benthic and consumer groups and fishing pressure, the CORSET outputs demonstrated reasonable correspondence with empirically observed points (Rodgers et al. 2010; Coyne et al. 2003) for benthic cover at the regional scale. Turf algae cover was modeled consistently higher than coral. CORSET accurately captured the wide discrepancy between turf algae and coral cover in Oahu and the Big Island of Hawai'i. The model output also indicated the mild decline in coral cover and corresponding increase in algal 
187 cover following three coral bleaching events, in 1996, 2002 and 2014, though not to as extreme a 188 degree as suggested by empirical data (Figs. 3, S5).

189

190

191

192

193

194

195

196

197

198

199

200

201

202

203

204

205

206

207

208

209

210

211

212

213

\section{Scenario Sweep}

Figures 4-6 and Tables 1, S4 and S5 indicate results for the Scenario Sweep outlined in Table S4.

Scenario Sweep: RCP 4.5 vs. RCP 8.5

In both climate scenarios, piscivore fisheries collapsed along with the coral community at large; this occurs to a lesser degree and later in RCP 4.5.

Scenario Sweep: RCP 8.5 + no-take MPAs

Coral cover was severely reduced under all examined no-take MPA scenarios. Fishing pressure led to declines in piscivore populations even for with $20 \%$ of reef areas within no-take MPAs.

Scenario Sweep: RCP $8.5+$ Nutrification

Decreases occurred in coral cover and piscivore biomass with related increases in turf algae cover, herbivore biomass, and macroalgae cover across the four time intervals (Fig. 5, Table S5).

Scenario Sweep: RCP 8.5 + no-take MPAs + Nutrification

Under increased nutrification, higher reef areas in no-take MPAs did not result in higher coral cover, as the decrease in coral larval production and increase in turf algae growth within four times more reef cells (e.g., from $5 \%$ to $20 \%$ of total cell area) overwhelms any top-down control on turf algae growth otherwise provided by a higher herbivore biomass (in high-MPA scenarios). During coral declines, fishery catch remained fairly stable but the catch composition shifted from a mix of piscivorous fishes and herbivorous fishes to predominantly herbivorous fishes (Fig. 7).

\section{Discussion}


While reef ecosystems can be difficult to capture using models, they are crucial to coastal communities and significantly threatened by a myriad of human and environmental processes. The CORSET model is a regional-scale biophysical model of coral reef ecosystems useful for testing future climate and management scenarios in the Main Hawaiian Islands. This instantiation of the CORSET model to the MHI demonstrated its ability to simulate real-world outcomes and respond reasonably to high-disturbance regimes. Since the model was originally developed as a decision support tool, we simulated a suite of management scenarios under projected coral bleaching regimes to explore the effect of various marine protected area sizes and nutrification loads on reef community state variable trajectories.

Hawaiian corals at the 100-year time horizon decline significantly in every scenario examined, including those with $20 \%$ fishery closures. However, these results do not suggest collapse of the entire reef community. The prevailing paradigm, that reducing fishing pressure will mitigate or even reverse a coral-algal phase shift, has been supported almost exclusively by work in the Caribbean and within one-time-point studies alone (Russ et al. 2015; Hughes et al. 2007; Bellwood et al. 2004; Mumby et al. 2006). A challenge to the ubiquity of the herbivorecoral relationship was recently addressed in Russ et al. (2015) wherein the relative simplicity of bottom-up regulation of fish populations by the benthos was posited as more likely and more strongly supported by long-term evidence in the Indo-Pacific than the more indirect and complex top-down hypothesis. Our study predicts region-wide decreases in coral cover yet a maintenance of herbivore biomass from increased algal populations. The reef fish fishery maintains a relatively stable trend catch by shifting the catch composition from a mix of piscivores and herbivores to predominately herbivorous fish by end of century (Fig. 7). 
Elementary effects analyses of nutrification and sedimentation for the complex integrated model from which CORSET originated (Fung 2009) indicate that nutrification exhibits a range of effects upon parameter outcomes; the largest being a positive upon turf algae growth. Its effects upon coral cover are negative but only moderately so (Fung 2009). In addition, multivariate evaluations of reef predictability indicate that, taken alone, forcings that remove fish biomass decrease the predictability of reef futures, whereas forcings that target coral cover (e.g. bleaching) create a small increase in predictability. Melbourne-Thomas et al. (2010) indicated that lower variability between model runs occurs under high coral loss, reflecting that degraded reefs converge on a community composition where algal cover is high, and where coral cover and the biomass of all fish groups is low. In our example, it follows that all outcomes reached stability at decreased or marginal coral cover and fishery biomass. In the nutrification sweep, we observed a decline in confidence for scenarios that introduced high levels of nutrients and stimulated turf algae growth, which competes with macroalgae for benthic space. This sweep retained the status quo for fishing, so that these scenarios were subject to forcings that both target fish biomass and complicate mid-level ecosystem processes (competition of algae), which may explain the decrease in predictability for later years in these simulations.

Most Hawaiian reefs are a thin veneer of reef-accreted calcium carbonate upon volcanic basalt bedrock (Grigg 1998). The basalt bedrock provides a complex reef geomorphology that will remain after corals decline and provide a benthic substrate for algal populations. We suggest that Nihoa Island and Gardner Pinnacle in the Northwestern Hawaiian Islands as two present-day reference points for the future of Hawaiian reefs described by our model results. These two areas are older islands that have eroded considerably but are surrounded by predominantly basalt rock bottom that has very low coral cover, high algal cover and high herbivore biomass 
approximately $300-400 \%$ greater than reefs in the main Hawaiian Islands (Friedlander \& DeMartini 2002). While the loss of corals and associated fine-scale reef structure will lead to an overall diminished fish biomass, the impacts should differentially affect particular fish groups. Our results suggest that herbivorous fishes in the Hawaiian Islands, especially around volcanic high islands, are ecological "winners" under climate change.

There is inherent uncertainty regarding the spatial variability of ecological parameters. The most considerable sources of uncertainty in this model are summarized in Table 2 . The model disregards seasonality entirely in terms of growth and recruitment. Finally, the model's structure and function itself is rooted in the assumption that the functional groups selected (and those disregarded) are the most appropriate; that uniform distributions of parameter values are biologically realistic; and that forcing outcomes follow a pattern.

The historical simulation of model trajectories did not capture the decline in coral cover that seems to be suggested by empirical data. Possible causes include the fact that the model does not account for coral disease, which readily takes hold in vulnerable (e.g. recently bleached) corals; it is also possible that the recruitment or growth parameters for living corals is higher than reality. CORSET restricts benthic cover to consist of either corals, turf algae, macroalgae, or epilithic algal communities, and does not account for other substrates as are recorded in surveys throughout the region. Accordingly, the model 'responds' to a loss of coral cover with the overgrowth of turfs and other algae, which may result in an exaggerated value as this total is required to sum to $100 \%$. In reality, dead coral typically yields to combination of algae, invertebrates, sand, rubble, and open space, the ignorance of which may make the difference between a persistent fish community (grazing an abundance of algae) and the successional collapse of higher trophic groups. Taken together, these warnings are meant to prevent marine 
managers from assuming that a loss in coral cover is irrelevant to the wellbeing of fisheries or coastal ecosystems.

We did not explore the effect of different bleaching regimes, since it is unlikely that regional managers would be able to control the biogeochemical and climactic factors that collude on a global scale to produce thermal anomalies leading to bleaching. However, a straightforward comparison between two IPCC Representative Concentration Pathway scenarios (RCPs) indicated that, while an emissions mitigation scenario (RCP 4.5) delays the diminishment of coral cover by a decade at least, both regimes involve bleaching events too frequent to sustain current benthic community compositions and result in a regional regime shift to an algaldominated state.

Another source of uncertainty for this model is the ability of the larval connectivity matrix approach to reflect true connectivity and recruitment processes between reef sites. While previously applied in multiple studies and informed by biophysical data for other locations (Pineda et al. 2007; Largier 2003), the connectivity matrices describe dynamics at a coarse spatial scale for the Hawaiian model and have only been validated with indirect observational data such as genetic approaches (Toonen et al. 2011). There is likely a stochastic element to larval connectivity dynamics in nearshore systems, whereas CORSET's model is based on persistent linkages between reefs over the study period.

These results should be interpreted with caution as there are ecological processes either overlooked or oversimplified within the CORSET model that may influence the viability of Hawaiian reefs under these low-cover paradigms. The model lacks any index or scaling factor for the value of benthic structure or rugosity over time. Dead and dying corals subside in tandem with turf algae overgrowth, at a rate which can only be expected to increase with higher ocean 
acidification (Pratchett et al. 2009; Edinger et al. 2000). Because complex coral structure is certainly tied to the recruitment and early life histories of reef fish, it is unreasonable to expect a scenario with $2 \%$ coral cover to support the same rate of fish survival as one with ten times that amount. It is possible that mass bleaching events may not lead to immediate structural loss, which highlights the concern that CORSET does not accommodate the ecosystem processes provided by living vs. dead or dying corals. While fish are able to persist (e.g. spawn and hide from predators) among dead coral skeletons, calcifying algae may not produce the same rugosity, and the collapse of higher trophic groups gives way to bio-eroders that would accelerate the loss of coral structure. A possible long-term strategy would be to restrain fishing below the level at which algae out-compete corals (McClanahan 1995), though considering the predicted annual frequency of chronic bleaching events, this seems somewhat futile. In our view, it is more realistic to recalibrate the targets and benchmarks of a sustainable fishery among low trophic groups. Considering it is much more difficult to manage the many factors (pollution, erosion, acidification) that modify the benthos than to impose a no-take MPA, the suggestion that the notake MPAs cannot guarantee a preservation of coral cover may complicate management priorities. It may require a reformulation of the target of conservation practices, with the acknowledgement that a great decline in coral cover is generally inevitable. No scenarios resulted in the persistence of higher trophic groups, suggesting that the amount of fishing pressure modeled was simply too high to sustain any semblance of current populations in the long-term future.

To summarize, we modeled a possible future wherein coral reefs shift to an algaedominated state that retains low coral cover and a functional biomass of herbivorous fishes that sustains a reef fish fishery. We explored the effects of no-take MPAs and increased coastal 
nutrients on coral reef benthic and consumer functional groups for Hawaiian coral reefs experiencing fishing and coral bleaching using the CORSET model under IPCC climate scenarios RCP 4.5 and RCP 8.5 for the years $2000-2100$. Coral mortality from bleaching events drove a lagged increase in herbivorous fish populations as a shift from coral-dominated to algaedominated habitats provided increased prey. Biomass and catch of piscivorous fish declined significantly with the fishery shifting to the harvest of herbivorous fish. No-take MPAs for $20 \%$ of reef areas represented a threshold that had a positive effect on herbivorous fishes but no influence on the steep declines of corals and piscivorous fishes. These results contradict the usual management paradigm, which emphasizes top-down ecosystem control (Mumby et al. 2006; Mumby et al. 2014; Brown \& Mumby 2014; Douvere 2008), and present a new challenge in discerning the most effective means of ecosystem management for all ecological components of coral reefs.

\section{Acknowledgements}

We thank J. Melbourne-Thomas for sharing the software code for CORSET, M. Donahue and C. Mora for suggestions in study design and analysis, M. Belcaid for providing code and computing resources for the sensitivity analyses, E. Treml for his contributions on larval connectivity in Hawaii, Z. Oyafuso for model parameter values mined from the literature, and two anonymous referees whose reviews contributed to the improvement of this manuscript. This work was supported by funding from the USGS Pacific Islands Climate Science Center (G13AC00395 to ECF) and NOAA Fisheries Pacific Islands Fisheries Science Center (NA10NMF4520163 to ECF). This is SOEST contribution \#9849 and HIMB contribution \#1669.

\section{References}


Ainsworth, C.H. \& Mumby, P.J., 2015. Coral-algal phase shifts alter fish communities and reduce fisheries production. Global Change Biology, 21(1), pp.165-172.

Ainsworth, C.H., Varkey, D.A. \& Pitcher, T.J., 2008. Ecosystem simulations supporting ecosystem-based fisheries management in the Coral Triangle, Indonesia. Ecological Modelling, 214(2-4), pp.361-374.

Bahr, K.D., Jokiel, P.L. \& Rodgers, K.S., 2015. The 2014 coral bleaching and freshwater flood events in Kāne'ohe Bay, Hawai'i. PeerJ, 3, p.e1136. Available at: https://peerj.com/articles/1136.

Bellwood, D.R. et al., 2004. Confronting the coral reef crisis. Nature, 429(6994), pp.827-833.

Brown, C.J. \& Mumby, P.J., 2014. Trade-offs between fisheries and the conservation of ecosystem function are defined by management strategy. FRONTIERS IN ECOLOGY AND THE ENVIRONMENT, 12(6), pp.324-329.

Buddemeier, R.W., Lane, D.R. \& Martinich, J.A., 2011. Modeling regional coral reef responses to global warming and changes in ocean chemistry: Caribbean case study. Climatic Change, 109(3-4), pp.375-397.

Coyne, M.S. et al., 2003. Benthic Habitats of the Main Hawaiian Islands URL: http://biogeo.nos.noaa.gov/projects/mapping/pacific. Also available on U. S. National Oceanic and Atmospheric Administration. National Ocean Service, National Centers for Coastal Ocean Science, Biogeogra.

De'ath, G. et al., 2012. From the Cover: The 27-year decline of coral cover on the Great Barrier Reef and its causes. Proceedings of the National Academy of Sciences, 109(44), pp.1799517999.

Dollar, S.J. \& Grigg, R.W., 2004. Anthropogenic and Natural Stresses on Selected Coral Reefs in Hawai'i: A Multidecade Synthesis of Impact and Recovery. Pacific Science, 58(2), pp.281-304. Available at: http://muse.jhu.edu/content/crossref/journals/pacific_science/v058/58.2dollar.pdf.

Douvere, F., 2008. The importance of marine spatial planning in advancing ecosystem-based sea use management. Marine Policy, 32(5), pp.762-771.

Eble, J. a. et al., 2011. Escaping paradise: Larval export from Hawaii in an indo-pacific reef fish, the yellow tang zebrasoma flavescens. Marine Ecology Progress Series, 428, pp.245-258.

Edinger, E.N. et al., 2000. Normal coral growth rates on dying reefs: Are coral growth rates good indicators of reef health? Marine Pollution Bulletin, 40(5), pp.404-425.

Franklin, E.C., Jokiel, P.L. \& Donahue, M.J., 2013. Predictive modeling of coral distribution and abundance in the Hawaiian Islands. Marine Ecology Progress Series, 481, pp.121-132. Available at: http://www.int-res.com/articles/meps2013/481/m481p121.pdf.

Friedlander, A.M. et al., 2003. Effects of habitat, wave exposure, and marine protected area status on coral reef fish assemblages in the Hawaiian archipelago. Coral Reefs, 22(3), pp.291-305.

Friedlander, A.M. et al., 2008. The state of coral reef ecosystems of the Main Hawaiian Islands. The State of Coral Reef Ecosystems of the United States and Pacific Freely Associated 
States: 2008, pp.219-253.

Friedlander, A.M., Brown, E.K. \& Monaco, M.E., 2007. Coupling ecology and GIS to evaluate efficacy of marine protected areas in Hawaii. Ecological Applications, 17(3), pp.715-730.

Friedlander, A.M. \& DeMartini, E.E., 2002. Contrasts in density, size, and biomass of reef fishes between the northwestern and the main Hawaiian islands: The effects of fishing down apex predators. Marine Ecology Progress Series, 230, pp.253-264.

Fung, T., 2009. Local scale models of coral reef ecosystems for scenario testing and decision support.

Grigg, R.W., 1998. Holocene coral reef accretion in Hawaii: A function of wave exposure and sea level history. Coral Reefs, 17(3), pp.263-272.

Hoegh-Guldberg, O., 1999. Climate change, coral bleaching and the future of the world's coral reefs. Marine and Freshwater Research, 50(8), p.839.

Hoeke, R.K. et al., 2011. Projected changes to growth and mortality of Hawaiian corals over the next 100 years. PLoS ONE, 6(3).

Van Hooidonk, R. et al., 2014. Opposite latitudinal gradients in projected ocean acidification and bleaching impacts on coral reefs. Global Change Biology, 20(1), pp.103-112.

Hughes, T.P. et al., 2007. Phase Shifts, Herbivory, and the Resilience of Coral Reefs to Climate Change. Current Biology, 17(4), pp.360-365.

Largier, J.L., 2003. Considerations in estimating larval dispersal distances from oceanographic data. Ecological Applications, 13(1 SUPPL.).

Layman, C. a. et al., 2011. Marine fisheries declines viewed upside down: Human impacts on consumer-driven nutrient recycling. Ecological Applications, 21(2), pp.343-349.

McClanahan, T.R., 1995. A coral reef ecosystem-fisheries model: Impacts of fishing intensity and catch selection on reef structure and processes. Ecological Modelling, 80(1), pp.1-19.

McManus, J.W. \& Polsenberg, J.F., 2004. Coral-algal phase shifts on coral reefs: Ecological and environmental aspects. Progress in Oceanography, 60(2-4), pp.263-279.

Melbourne-Thomas, J. et al., 2011. A multi-scale biophysical model to inform regional management of coral reefs in the western Philippines and South China Sea. Environmental Modelling and Software, 26(1), pp.66-82.

Melbourne-Thomas, J., 2010. Decision Support Tools for Visualising Coral Reef Futures at Regional Scales. Scenario, (September), p.169. Available at: http://eprints.utas.edu.au/10744/.

Melbourne-Thomas, J. et al., 2011. Regional-scale scenario modeling for coral reefs: A decision support tool to inform management of a complex system. Ecological Applications, 21(4), pp.1380-1398.

Miller, J. et al., 2009. Coral disease following massive bleaching in 2005 causes $60 \%$ decline in coral cover on reefs in the US Virgin Islands. Coral Reefs, 28(4), pp.925-937.

Most, R.J., 2012. Nutrient and Herbivory Effects on Benthic Marine Algal Biomass and Community Structure on the Kona Coast of Hawaii. 
Mumby, P.J. et al., 2014. Operationalizing the Resilience of Coral Reefs in an Era of Climate Change. CONSERVATION LETTERS, 7(3), pp.176-187. Available at: http://onlinelibrary.wiley.com/store/10.1111/conl.12047/asset/conl12047.pdf? $\mathrm{v}=1 \& \mathrm{t}=\mathrm{i} 5 \mathrm{~g} 2 \mathrm{u}$ e9p\&s=d5fa543ef91b3532522860b86a546294e61457bf.

Mumby, P.J. et al., 2006. Process of Grazing on Coral Reefs. Science, 311(5757), pp.98-101. Available at: http://www.ncbi.nlm.nih.gov/pubmed/16400152.

Mumby, P.J., 2006. The Impact of Exploiting Grazers (Scaridae) on the Dynamics of Caribbean Coral Reefs. Ecological Applications, 16(2), pp.747-769. Available at: $<$ Go to ISI $>$ ://000237052200027.

Osborne, K. et al., 2011. Disturbance and the dynamics of coral cover on the Great Barrier Reef (1995-2009). PLoS ONE, 6(3).

Paddack, M.J., Cowen, R.K. \& Sponaugle, S., 2006. Grazing pressure of herbivorous coral reef fishes on low coral-cover reefs. Coral Reefs, 25(3), pp.461-472.

Pineda, J., Hare, J.A. \& Sponaugle, S., 2007. Larval Transport and Dispersal in the Coastal Ocean and Consequences for Population Connectivity. Oceanography, 20(3), pp.22-39.

Pooley, S.G., 1993. Hawaii 's Marine Fisheries : Some History, Long-term Trends , and Recent Developments. Marine Fisheries Review, 55(2), pp.7-19.

Pratchett, M.S. et al., 2009. Coral Bleaching and Consequences for Motile Reef Organisms: Past, Present and Uncertain Future Effects. In M. J. H. Oppen \& J. M. Lough, eds. Coral Bleaching: Patterns, Processes, Causes and Consequences. Springer Berlin Heidelberg, pp. 139-158. Available at: http://dx.doi.org/10.1007/978-3-540-69775-6_9.

Python Software Foundation, 2011. Python Programming Language - Official Website. pythonorg, (February 13, 2011). Available at: http://www.python.org/.

Riahi, K. et al., 2011. RCP 8.5-A scenario of comparatively high greenhouse gas emissions. Climatic Change, 109(1), pp.33-57.

Rodgers, K.S. et al., 2010. Quantifying the condition of Hawaiian coral reefs. AQUATIC CONSERVATION-MARINE AND FRESHWATER ECOSYSTEMS, 20(1), pp.93-105. Available at: http://onlinelibrary.wiley.com/store/10.1002/aqc.1048/asset/1048_ftp.pdf? v=1\&t=i5g2xr1o $\& \mathrm{~s}=\mathrm{be} 8 \mathrm{~b} 2 \mathrm{f} 64 \mathrm{f} 7 \mathrm{ef} 65411618 \mathrm{ad} 9718 \mathrm{a} 6 \mathrm{e} 4 \mathrm{e} 532 \mathrm{~d} 9 \mathrm{c} 6 \mathrm{f} 7$.

Rogers, A. et al., 2015. Anticipative management for coral reef ecosystem services in the $21 \mathrm{st}$ century. Global Change Biology, 21, pp.504-514.

Rooney, J. et al., 2004. EL Nino Influence on Holocene Reef Accretion in Hawai'i. Pacific Science, 58(2), pp.305-324. Available at: http://muse.jhu.edu/content/crossref/journals/pacific_science/v058/58.2rooney.pdf.

Russ, G.R. et al., 2015. The parrotfish-coral relationship: refuting the ubiquity of a prevailing paradigm. Marine Biology, 162(10), pp.2029-2045.

Selig, E.R., Casey, K.S. \& Bruno, J.F., 2010. New insights into global patterns of ocean temperature anomalies: Implications for coral reef health and management. Global Ecology and Biogeography, 19, pp.397-411. 
471 Toonen, R.J. et al., 2011. Defining Boundaries for Ecosystem-Based Management: A

472

473

474

475

476

477

478

479

480

481

482

483

484

485 Multispecies Case Study of Marine Connectivity across the Hawaiian Archipelago. Journal of Marine Biology, 2011, pp.1-13.

van Vuuren, D.P. et al., 2011. The representative concentration pathways: An overview. Climatic Change, 109(1), pp.5-31.

Walsh, W. et al., 2013. Long-Term Monitoring of Coral Reefs of the Main Hawaiian Islands Final Report Hawai ' i Island Monitoring Report.

Ware, J.R., Fautin, D.G. \& Buddemeier, R.W., 1996. Patterns of coral bleaching: modeling the adaptive bleaching hypothesis. Ecological Modelling, 84(1-3), pp.199-214.

Weijerman, M., Fulton, E.A. \& Parrish, F.A., 2013. Comparison of coral reef ecosystems along a fishing pressure gradient. PLoS One, 8(5), p.e63797.

Williams, I.D. et al., 2016. Responses of Herbivorous Fishes and Benthos to 6 Years of Protection at the Kahekili Herbivore Fisheries Management Area, Maui. PLoS ONE, 2010(7), pp.1-20. 
Parameter

Coral cover $(\%)$

Turf algae cover (\%)

Herbivorous Biomass

$(\mathrm{kg} / \mathrm{km} 2)$

Piscivorous Biomass

$(\mathrm{kg} / \mathrm{km} 2)$
Low no-take MPA (5\%)

Decreases coincident to bleaching
events

Increases over time; consistently higher than scenarios with greater protection

Generally stable over time

Collapses after 2050; consistently

lower than more-protected scenarios
High no-take MPA (20\%)

Decreases coincident to bleaching events at slowest rate

Increases over time; consistently lower than scenarios with less protection

Generally stable over time

Nearly collapses after 2050; barely higher than scenarios with less protection

489 Table 1. Summary of state variable responses to varied marine protected area regimes

490 within scenario sweep.
Category
Description
Suggestions

$\begin{array}{ll}\text { Larval Connectivity } & \begin{array}{l}\text { Difficult to validate connectivity } \\ \text { data derived from larval } \\ \text { dispersal simulations }\end{array} \\ \text { Parameter Uncertainty } & \begin{array}{l}\text { Spatial, temporal variability } \\ \text { uncertain; uncertainty in } \\ \text { production parameters }\end{array} \\ \text { Simplification of ecological } & \text { Use of uniform distribution for } \\ \text { parameter selection; lack of } \\ \text { temporal and spatial variability; } \\ \text { broad assumptions about fishing } \\ \text { pressure (e.g., linear increases) }\end{array}$




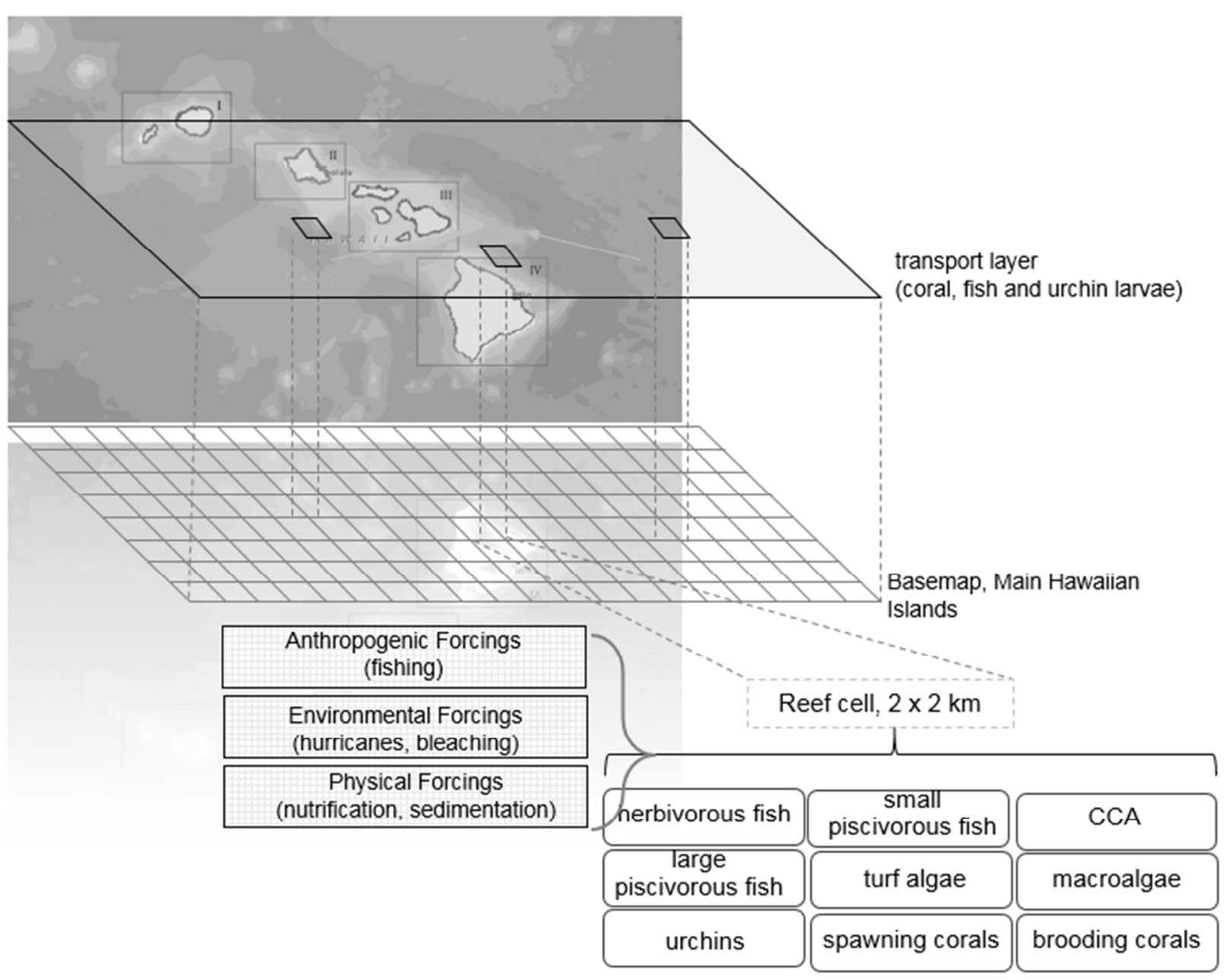

494 Figure 1. Schematic of structure and function in CORSET. Mean-field equations describing

495 local-scale interactions between benthic and consumer functional groups are instantiated in 496 each reef cell of a gridded base-map. Reef cells are connected through larval transport,

497 which is defined by connectivity matrices of transition probabilities for each of (spawning)

498 coral, fish and sea urchin larvae. Fishing, nutrification and sedimentation are modeled as

499 external forcings. Map created using ArcGIS ${ }^{\circledR}$ software by Esri, www.esri.com. 

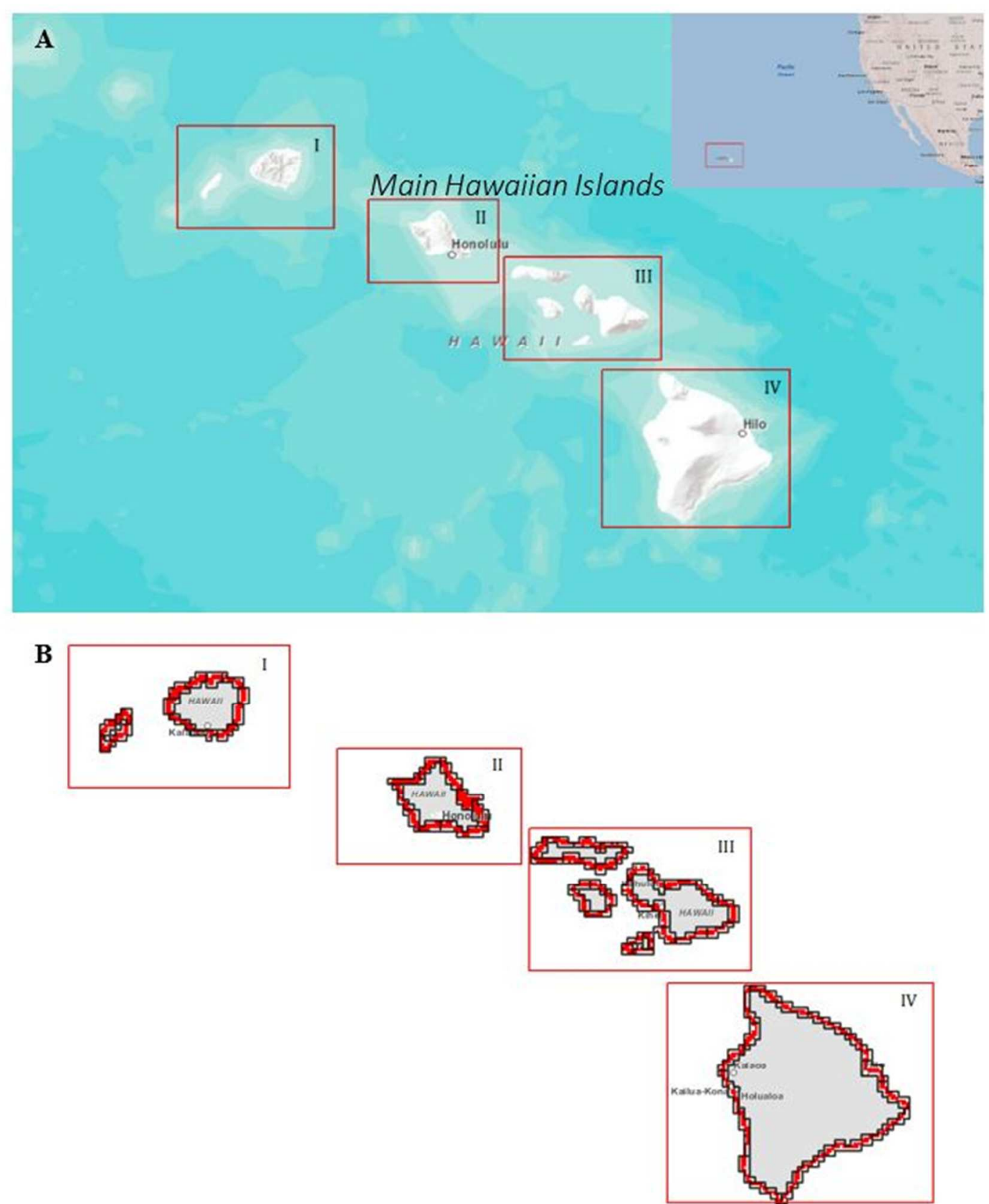

501 Figure 2A,B. Visualization of basemap constructed for the MHI instantiation of CORSET.

502 A) Main Hawaiian Islands, the model domain, with four subregions indicated in red boxes:

503 I: Kauai-Ni'ihau II: O’ahu III: Maui Nui (islands of Maui, Lana'i, Moloka'i and

504 Kaho'olawe) IV: Big Island of Hawaii. B) Gridded $4 \mathrm{~km} 2$ x $4 \mathrm{~km} 2$ basemap; each cell 
505 represents a reef. Thick black outlines denote larval connectivity polygons. Map created 506 using ArcGIS ${ }^{\circledR}$ software by Esri, www.esri.com.

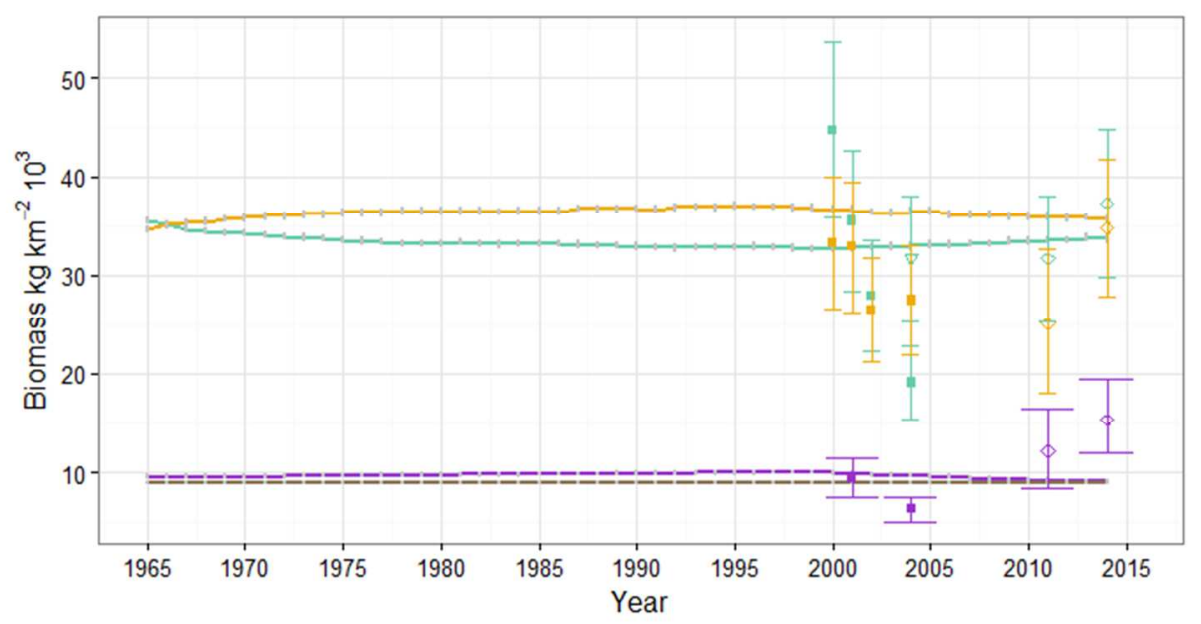

$\rightarrow$ Herbivores

$\rightarrow$ L Piscivores

$\rightarrow$ S Piscivores

$\rightarrow$ Urchins

survey

- Coyne et al. (2013)

$\diamond$ NOAA, unpubl.

$\checkmark$ Rodgers et al. (2010)

- Rodgers et al. (2015)
508

509

510

511

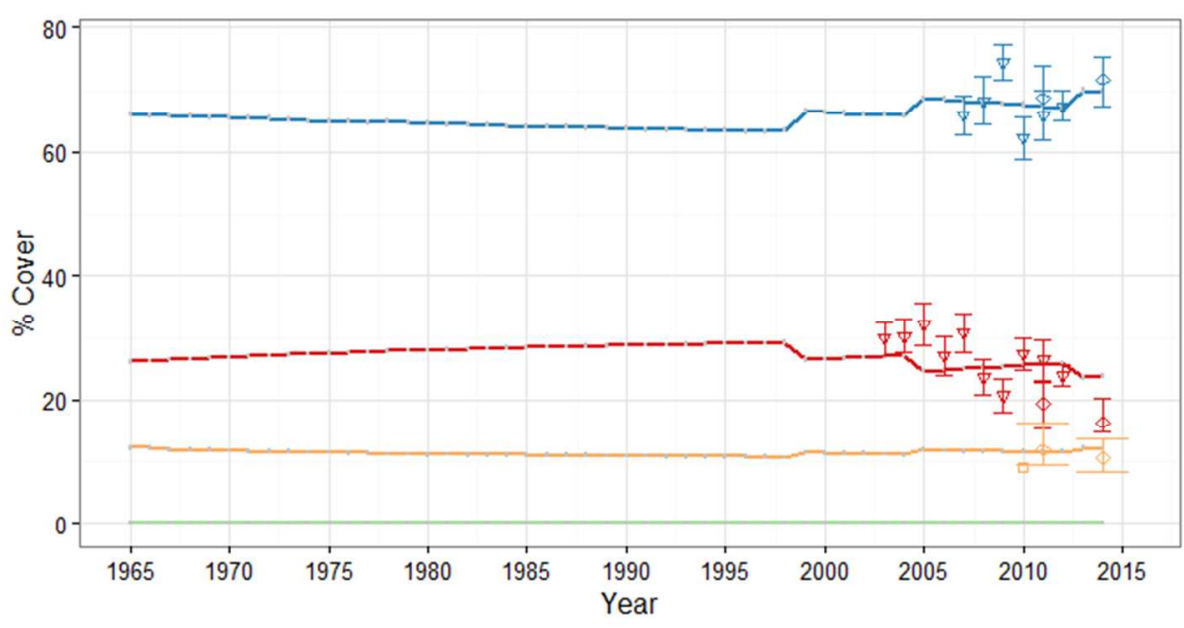

$\rightarrow$ Coral

$\rightarrow$ EAC

Macroalgae

- Turf Algae

survey

- Coyne et al. (2013)

$\diamond$ NOAA, unpubl.

$\checkmark$ Rodgers et al. (2010)

- Rodgers et al. (2015)

Figure 3. Regional model trajectories for consumer (upper) and benthic (lower) parameters from 1965 to present from 100 Monte Carlo runs. Grey points represent 95\% confidence intervals for each year. 

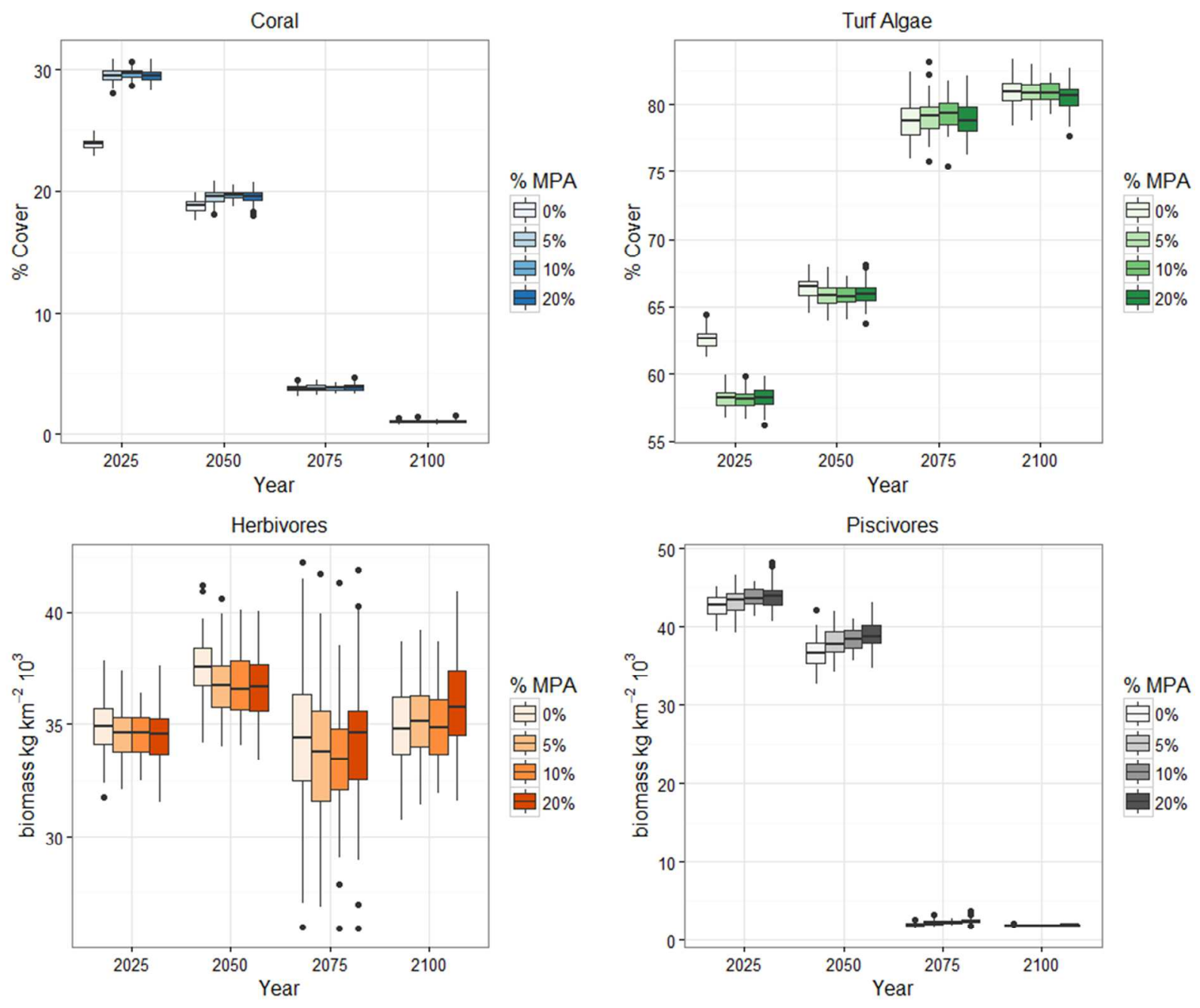

513 Figure 4. Modeled state variable responses for four no-take MPA scenarios under RCP 8.5.

514 Each panel represents a single response variable; individual boxes are color-coded by the 515 percentage of reef cells closed to fishing activity. 

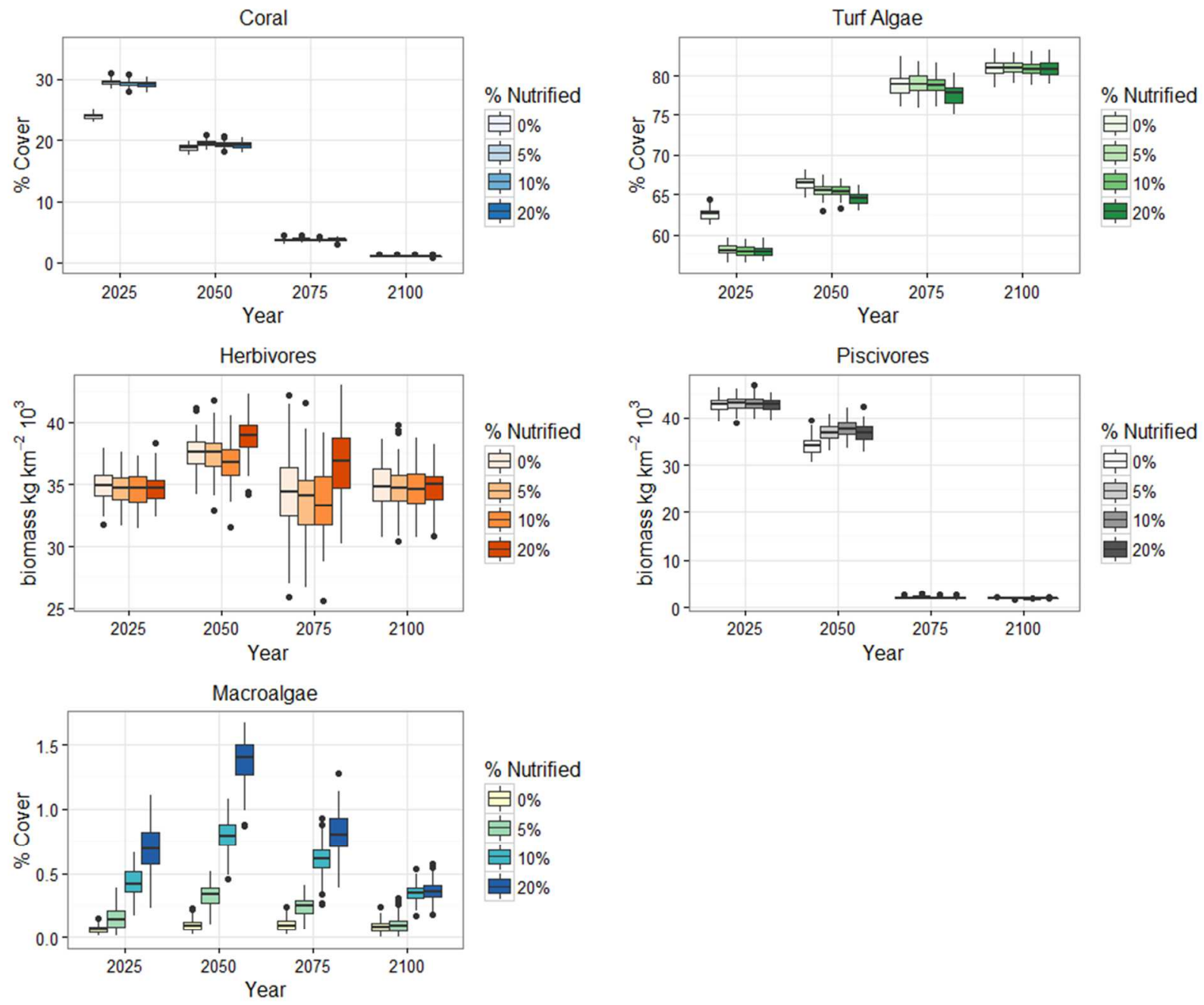

517 Figure 5. Modeled state variable responses for four nutrification regimes under RCP 8.5.

518 Each panel represents a single response variable; individual boxes are color-coded by the 519 percentage of reef cells affected by nutrification. 

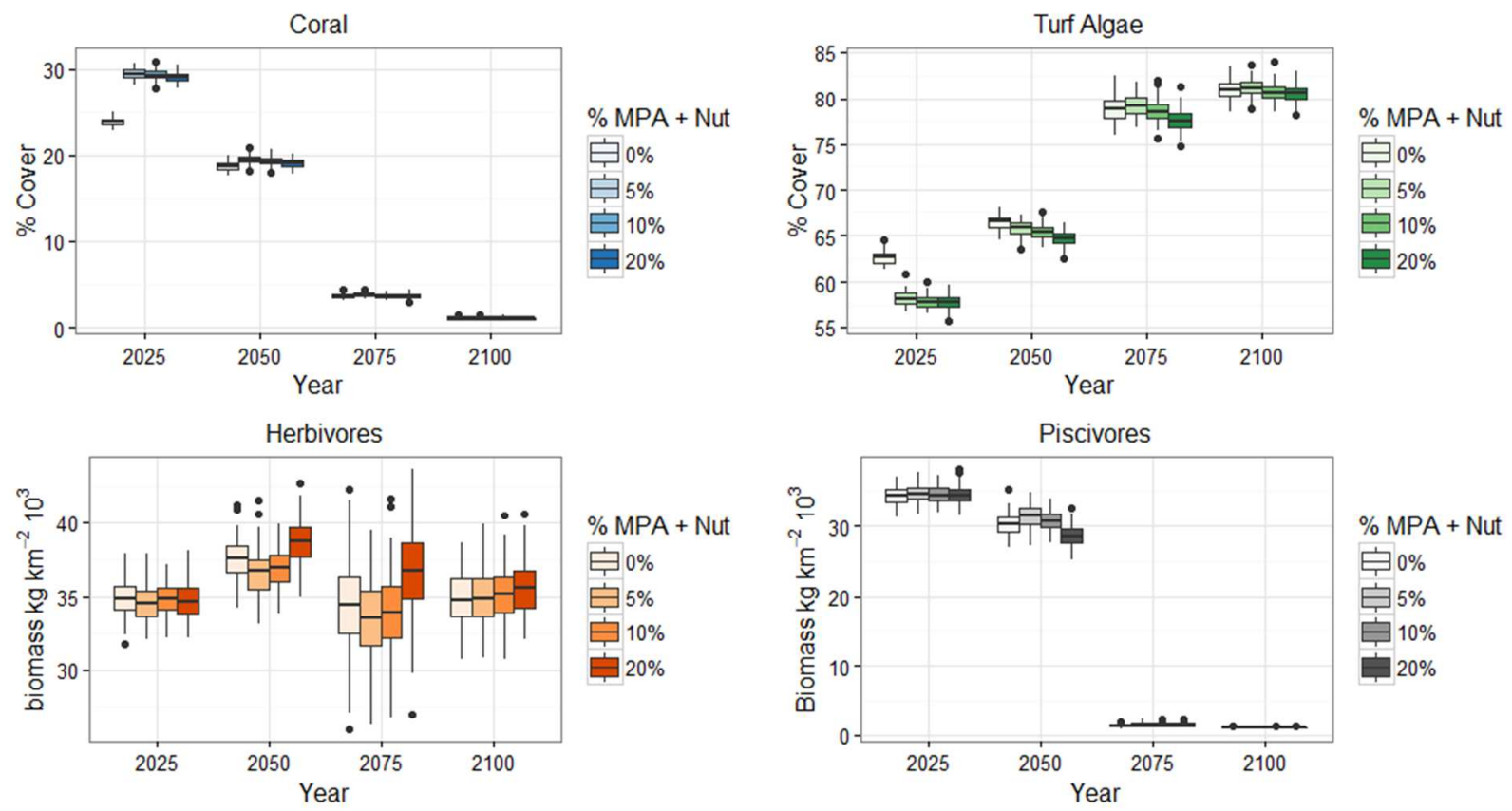

521
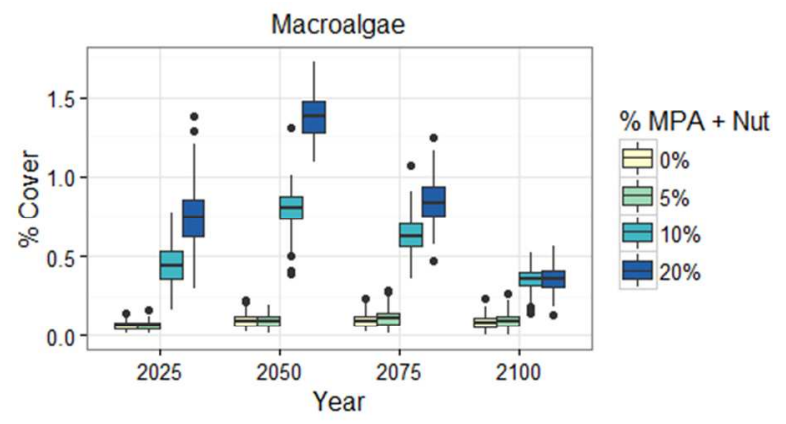

522 Figure 6. Modeled state variable responses for four paired no-take MPA + nutrification

523 regimes under RCP 8.5. Each panel represents a single response variable; individual boxes

524 are color-coded by the percentage of reef cells affected by nutrification and closed to

525 fishing activity.

526

527 

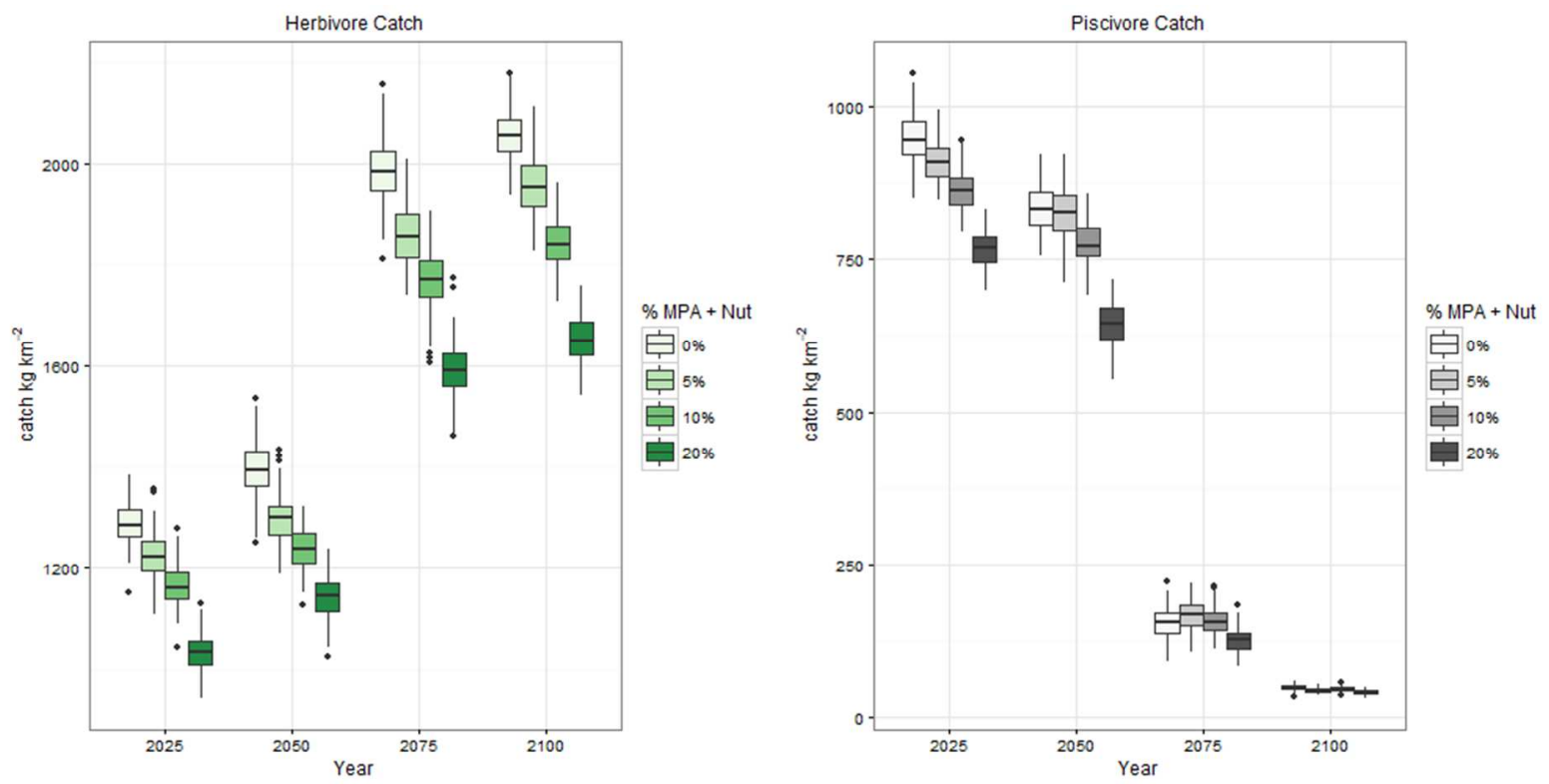

529 Figure 7. Fishery catch of herbivorous fishes and piscivorous fishes for no-take MPA +

530 nutrification regimes under RCP 8.5. Each panel represents a single response variable; individual

531 boxes are color-coded by the percentage of reef cells affected by nutrification and closed to

532 fishing activity. 
1 Local Scale Ecological Model.

2 Please refer to the following for a detailed exploration of equilibrium behavior and parameter

3 sensitivities for both the local-scale, differential (continuous) system from which CORSET was

4 derived, and the discrete-time equation array that constitutes the model used here:

5 Jessica Melbourne-Thomas, Craig R. Johnson, Tak Fung, Robert M. Seymour, Laurent M.

6 Chérubin, J. Ernesto Arias-González, and Elizabeth A. Fulton. 2011. Regional-scale scenario

7 modeling for coral reefs: a decision support tool to inform management of a complex

8 system. Ecological Applications 21:1380-1398. The local-scale ecological model (Ecological

9 Archives A021-064-A).

Table A1. Local model parameter definitions and values derived for the Main Hawaiian Islands.

11 Parameter values are derived using the same parameterization methodology as detailed in Fung

12 (2009). Mathematically derived parameter restrictions detailed in the footnotes are required to

13 keep state variables within a realistic biological range, i.e. in the range $0-1$ for benthic covers,

14 and $\geq 0$ (but not tending to infinity) for consumer biomasses (see Fung, 2009, for detailed

15 derivations).

\section{Benthic Parameters}

0.02-0.1 yr- $-^{1}$ (Bythell, Gladfelter, \&

$\mathrm{d}_{\mathrm{C}} \quad$ The background mortality rate of brooding and spawning corals Bythell, 1993; Lirman, 2003; Nugues \& Bak, 2006)

$0.04-0.2 \mathrm{yr}^{-1}$ (Babcock, 1985;

$\mathrm{r}_{\mathrm{C}} \quad$ The growth rate of existing coral over grazed EAC

Chornesky \& Peters, 1987; Edmunds, 2007; Huston, 1985; Koop et al., 2001; Langmead \& Sheppard, 2004;

Sandin et al., 2008)

$a_{C} \quad$ The growth rate of coral over macroturf, relative to its growth over grazed EAC

$$
0-1
$$

The recruitment rate of coral onto macroturf, relative to the rate onto grazed EAC

0.05-0.15(Birrell et al., 2005)

$\xi_{\mathrm{Cb}}, \xi_{\mathrm{Cs}}^{\mathrm{a}}$

The recruitment rates of brooding and spawning corals onto

$$
\text { grazed EAC }
$$

Modeled separately 
$\mathrm{g}_{\mathrm{T}}$

$\zeta_{\mathrm{T}}$

$\mathrm{g}_{\mathrm{M}}$

$r_{M}$

The growth rate of macroalgae over grazed EAC existing macroturf is grazed down existing macroalgae is grazed down
The maximum rate (per unit of grazing pressure $\theta$ ) at which

The rate at which grazed EAC grows into macroturf

The maximum rate (per unit of grazing pressure $\theta$ at which

Coral growth is inhibited by the presence of nearby macroalgae $\beta_{\mathrm{M}} \quad$ and this is represented as a depression of $\mathrm{r}_{\mathrm{C}}$ by the factor (1 $\left.-\beta_{\mathrm{M}} \mathrm{M}\right) 27$

$\gamma_{\mathrm{MC}}$ $\gamma_{\mathrm{MT}}$

The growth rate of macroalgae over coral, relative to its growth over grazed EAC

The growth rate of macroalgae over macroturf, relative to its growth over grazed EAC

\section{Consumer parameters}

$5-15 \mathrm{yr}^{-1}$ (Birrell et al., 2005; Mumby \& Dytham, 2006)

2- $20 \mathrm{yr}^{-1}$ (McClanahan, Polunin, \&

Done, 2002; Mumby \& Dytham, 2006)

$0.05-15 \mathrm{yr}^{-1}$ (Bellwood, Hughes, \& Hoey, 2006; Hay, 1991; Hughes et al., 2007; Mumby \& Dytham, 2006; G R Russ \& St. John, 1988; Garry R. Russ, 2003)

0.05-0.4 $\mathrm{yr}^{-1}$ (Mumby, Foster, \& Fahy, 2005)

0.4-0.9 yr-1 (Arias-González, 1998;

Babcock, 1985; Chornesky \& Peters, 1987; Edmunds, 2007; Garcia-

Salgado \& Nava-Martinez, 2008; Hay, 1984; Huston, 1985; Koop et al., 2001; Langmead \& Sheppard, 2004;

Sandin et al., 2008; Van Rooij, Videler, \& Bruggemann, 1998)

0-0.9 (Box \& Mumby, 2007;

Mumby et al., 2005; Nugues \& Bak, 2006)

0-0.9 (Box \& Mumby, 2007; Mumby et al., 2005; Nugues \& Bak, 2006)

$3 \times 10^{3}-5 \times 10^{5} \mathrm{~kg} / \mathrm{km}^{2}$ (Aliño et al., 1993; Arias-González, 1998; S. R.

Carpenter, Kitchell, \& Hodgson, 1985; Craig, Green, \& Tuilagi, 2008;

Friedlander \& DeMartini, 2002;

Garcia-Salgado \& Nava-Martinez, 2008; Gardner, Côté, Gill, Grant, \& $\mathrm{i}_{\mathrm{H}} \quad$ A parameter that measures the inaccessibility of algae (turf and Watkinson, 2005; Gribble, 2003; P. a. macroalgae) to herbivorous fish grazing

Kramer, 2003; Letourneur, Kulbicki, \& Labrosse, 1998; Mangi \& Roberts, 2007; McClanahan, Kamukuru, Muthiga, Yebio, \& Obura, 1996; Newman, Paredes, Sala, \& Jackson, 2006; Sandin et al., 2008; Tsehaye \& Nagelkerke, 2008; Van Rooij et al., 1998; Williams \& Hatcher, 1983) $7 \times 10^{3}-1 \times 10^{4} \mathrm{~kg} / \mathrm{km}^{2}$ (Aliño et al., 1993; Arias-González, 1998; S. R. Carpenter et al., 1985; Craig et al., 


\section{$\mathrm{i}_{\mathrm{FH}}$ \\ $\mathrm{dH}^{\mathrm{b}}$ \\ $\rho \mathrm{H}$ \\ $\xi \mathrm{H}^{\mathrm{a}}$ \\ $\mu_{\mathrm{M},} \mu_{\mathrm{T}}, \mu_{\mathrm{E}}{ }^{\mathrm{c}}$ \\ $\mathrm{i}_{\text {PIPs }}$}

$\mathrm{i}_{\text {FPs }}$
A parameter that measures the inaccessibility of herbivorous fish to fishers

The death rate of herbivorous fish from all factors other than predation by piscivorous fish and fishing

The herbivorous fish biomass accumulated from grazing on $100 \%$ cover of macroalgae, macroturf and EAC respectively, and which contributes to somatic growth of herbivorous fish

A parameter that measures the inaccessibility of small-tointermediate piscivorous fish to predation by large piscivorous fish

A parameter that measures the inaccessibility of small-tointermediate piscivorous fish to fishermen
2008; Friedlander \& DeMartini, 2002; Garcia-Salgado \& NavaMartinez, 2008; Gardner et al., 2005;

Gribble, 2003; P. a. Kramer, 2003;

Letourneur et al., 1998; Mangi \& Roberts, 2007; McClanahan et al., 1996; Newman et al., 2006; Sandin et al., 2008; Tsehaye \& Nagelkerke, 2008; Van Rooij et al., 1998; Williams \& Hatcher, 1983)

$$
7 \times 10^{2}-1 \times 10^{3} \mathrm{~kg} / \mathrm{km}^{22,31-38}
$$

$0.3-3 \mathrm{yr}^{-1}$ (Froese \& Pauly, 2011) $900-5 \times 10^{5} \mathrm{~kg} \mathrm{~km}^{-2} \mathrm{yr}^{-1}$ (Aliño et al., 1993; Arias-González \& Morand, 2006; Arias-González, 1998;

Bellwood, Hughes, Folke, \& Nyström, 2004; Ebert, 1975; Gardner et al., 2005; Gribble, 2003; Johnson, Klumpp, Field, \& Bradbury, 1995; Van Rooij et al., 1998)

$$
0-1
$$

Modeled separately $7 \times 10^{3}-1 \times 10^{4} \mathrm{~kg} / \mathrm{km}^{2}$ (Aliño et al., 1993; Arias-González, 1998; R. C. Carpenter, 1986; Craig et al., 2008; Edwards et al., 2014; Friedlander \& DeMartini, 2002; Garcia-Salgado \& Nava-Martinez, 2008; Gardner et al., 2005; Gribble, 2003; P. a. Kramer, 2003; Letourneur et al., 1998; Mangi \& Roberts, 2007; McClanahan, 1996; Newman et al., 2006; Tsehaye \& Nagelkerke, 2008; Van Rooij et al., 1998; Williams \& Hatcher, 1983)

$7 \times 10^{2}-1 \times 10^{3} \mathrm{~kg} / \mathrm{km}^{2}$ (Aliño et al., 1993; Arias-González, 1998; R. C. Carpenter, 1986; Craig et al., 2008; Edwards et al., 2014; Friedlander \& DeMartini, 2002; Garcia-Salgado \& Nava-Martinez, 2008; Gardner et al., 2005; Gribble, 2003; P. a. Kramer, 


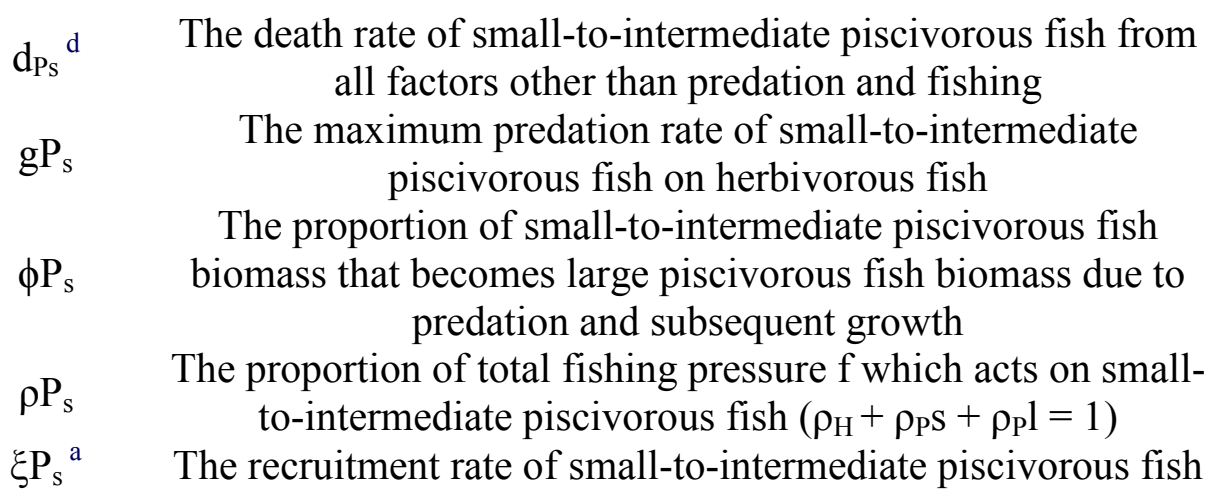

$\mathrm{i}_{\mathrm{FPl}}$

A parameter that measures the inaccessibility of large piscivorous fish to fishermen

The death rate of large piscivorous fish from all factors other $\mathrm{dP}_{1}^{\mathrm{e}}$ $\mathrm{gP}_{1}$ $\mathrm{rP}_{1}$

$\mathrm{P}_{1}$ $\rho \mathrm{P}_{1}^{\mathrm{f}}$ $\mathrm{f}$ $\mathrm{qU}^{\mathrm{g}}$ $d U^{f}$

$\mathrm{K}_{\mathrm{U}}$ $\xi \mathrm{U}^{\mathrm{a}}$ than predation and fishing 25

The maximum predation rate of large piscivorous fish on herbivorous fish

The proportion of consumed biomass which is used for somatic growth, for large piscivorous fish

The predation rate on small-to-intermediate piscivorous fish by large piscivorous fish, relative to that on herbivorous fish The proportion of total fishing pressure $f$ which acts on large piscivorous fish $\left(\rho_{\mathrm{H}}+\rho_{\mathrm{Ps}}+\rho_{\mathrm{Pl}}=1\right)$

The maximum fishing biomass which can be caught Quadratic mortality of urchins

The death rate of urchins

A parameter that measures the biomass accumulated by urchin grazing and which contributes to somatic growth relative to that for herbivorous fish grazing The recruitment rate of urchins
2003; Letourneur et al., 1998; Mangi \& Roberts, 2007; McClanahan, 1996;

Newman et al., 2006; Tsehaye \&

Nagelkerke, 2008; Van Rooij et al., 1998; Williams \& Hatcher, 1983) dPsmin -2 yr-1 (Froese \& Pauly, 2011)

$$
\begin{gathered}
1-2 \mathrm{yr}^{-1} \\
0-10 \\
0-1
\end{gathered}
$$

Modeled separately

0.2 - $3 \mathrm{yr}^{-1}$ (Aliño et al., 1993; AriasGonzález, 1998; R. C. Carpenter, 1986; Craig et al., 2008; Edwards et al., 2014; Friedlander \& DeMartini, 2002; Garcia-Salgado \& NavaMartinez, 2008; Gardner et al., 2005; Gribble, 2003; P. a. Kramer, 2003; Letourneur et al., 1998; Mangi \& Roberts, 2007; McClanahan, 1996; Newman et al., 2006; Tsehaye \& Nagelkerke, 2008; Van Rooij et al., 1998; Williams \& Hatcher, 1983)

$$
\begin{gathered}
7 \times 10^{2}-1 \times 10^{3} \mathrm{~kg} / \mathrm{km}^{2} \text { (Froese } \& \\
\text { Pauly, 2011) } \\
0.25-0.75 \mathrm{yr}^{-1} \\
0.03-0.09 \\
2-4 \\
0-1 \\
0-5 \times 10^{3} \mathrm{~kg} \mathrm{~km}^{-2} \mathrm{yr}^{-1} \\
5 \mathrm{x} 10^{7} \mathrm{yr}^{-1}{ }^{-1} \\
0.05-0.6 \mathrm{yr}^{-1} \\
0.7-3 \\
\text { Modeled separately }
\end{gathered}
$$


$\lambda \mathrm{H} \quad$ A parameter that determines the competitiveness of herbivorous fish relative to urchins

$0.6-1$

\section{$\lambda \mathrm{U}$} A parameter that determines the competitiveness of urchins relative to herbivorous fish

$1-3 \times 10^{6} \mathrm{~kg} / \mathrm{km}^{2}$

\section{$\mathrm{iU}^{\mathrm{h}}$}

A parameter that macroalgae) to urchin grazing

$$
2 \times 10^{3}-2 \times 10^{6}
$$

$17{ }^{\mathrm{a}}$ Recruitment terms $\left(\mathrm{l}_{\mathrm{Cb}}, \mathrm{l}_{\mathrm{Cs}}, \mathrm{l}_{\mathrm{H}}, \mathrm{l}_{\mathrm{Ps}}, \mathrm{l}_{\mathrm{U}}\right)$ are modeled externally to the local model, based on 18 matrices defining connectivity between reef cells. Parameters used for modelling larval

19 production and post-settlement processes are provided in Appendix D.

$20{ }^{\mathrm{b}} \mathrm{d}_{\mathrm{H} \min }=\left\{0.2, \frac{\max \{0.2, \mu \times \max \{\mathrm{gT}, \zeta \mathrm{T}\}\}}{i_{H}}+0.000001\right\}$

21

$22 \mu_{\max }=$

$23 \min \left\{100,000, \mu_{\max 1}\right\}$, where $\mu_{\max 1}=$

$24 \min \left\{\frac{\left.i_{H} \times(2-0.000001)\right\}}{\max \{\mathrm{gT}, \zeta \mathrm{T}\}}, \frac{\left.i_{U} \times(1-0.000001)\right\}}{K_{U} \times \max \{\mathrm{gT}, \zeta \mathrm{T}\}}\right\}$

$25{ }^{\mathrm{d}} d_{\mathrm{Psmin}}=\max \{0.2,(1-$

26 (фPs ) $\left.\mathrm{r}_{\mathrm{Ps}} g_{\mathrm{Ps}}\right\}$

$27{ }^{\mathrm{e}} d_{\mathrm{Plmin}}=r_{P l} g_{P l}\left(1+\varphi_{P l}\right)+0.00001$

28

${ }^{\mathrm{f}} d_{U \min }=\max \left\{0.3, \frac{K_{U} \mathrm{x} \mu \mathrm{x} \max \{g T, \zeta T\}}{i_{U}}+\right.$

$29 \quad 0.000001\}$

$30{ }^{\mathrm{g}}$ Quadratic mortality of sea urchins, $\mathrm{q}$, is included in the regional implementation of the local 31 ecological model to prevent uncontrolled population explosions in this functional group. This 32 term is a proxy for consumption of sea urchins by fish and invertebrate predators(Mumby, 33 Dahlgren, Harborne, Kappel, Micheli, Brumbaugh, Holmes, Mendes, Broad, Sanchirico, Buch, 34 Box, et al., 2006; Randall, Schroeder, \& Starck II, 1964).

$35{ }^{\mathrm{h}} i_{U \min }=\max \left\{2000, \frac{60 K_{U} \times \max \{g T, \zeta T\}}{1-0.00001}\right\}$ 
Table A2. Larval Production, Recruitment and Post-Settlement Parameters used in CORSET.

\begin{tabular}{|c|c|c|c|c|c|}
\hline $\begin{array}{l}\text { Recruitment } \\
\text { Parameters }\end{array}$ & Definition & Hawai'i & Type & Source(s) & Notes \\
\hline 1_C $*$ & $\begin{array}{l}\text { Brooding and spawning coral } \\
\text { larval production (at } 100 \% \\
\text { cover) }\end{array}$ & $\begin{array}{c}6 \times 10^{9}-9 \times 10^{9} \\
\mathrm{~km}^{-2} \mathrm{yr}^{-1}\end{array}$ & & $\begin{array}{c}\text { (Harrison \& } \\
\text { Wallace, 1990; } \\
\text { Richmond, 1988) }\end{array}$ & $\begin{array}{l}\text { Calibration parameter because info are } \\
\text { sparse, uncertain, and variable. As a } \\
\text { result, these values will remain the } \\
\text { same. }\end{array}$ \\
\hline $1 \_\mathrm{H} *$ & $\begin{array}{l}\text { Herbivorous fish larval } \\
\text { production }\end{array}$ & $\begin{array}{c}4 \times 10^{3}-1 \times 10^{4} \\
\mathrm{~kg}^{-1} \mathrm{yr}^{-1}\end{array}$ & & $\begin{array}{c}\text { (Cowen, Paris, \& } \\
\text { Srinivasan, 2006; } \\
\text { Froese \& Pauly, } \\
\text { 2011) }\end{array}$ & $\begin{array}{l}\text { Calibration parameter because info are } \\
\text { sparse, uncertain, and variable. As a } \\
\text { result, these values will remain the } \\
\text { same }\end{array}$ \\
\hline 1_Ps * & $\begin{array}{l}\text { Small piscivorous fish larval } \\
\text { production }\end{array}$ & $\begin{array}{c}1 \times 10^{2}-6 \times 10^{2} \\
\mathrm{~kg}^{-1} \mathrm{yr}^{-1}\end{array}$ & & $\begin{array}{l}\text { (Cowen et al., } \\
\text { 2006; Froese \& } \\
\text { Pauly, 2011) }\end{array}$ & $\begin{array}{l}\text { Calibration parameter because info are } \\
\text { sparse, uncertain, and variable. As a } \\
\text { result, these values will remain the } \\
\text { same }\end{array}$ \\
\hline 1_P1 * & $\begin{array}{l}\text { Large piscivorous fish larval } \\
\text { production }\end{array}$ & $\begin{array}{c}1 \times 10^{3}-6 \times 10^{3} \\
\mathrm{~kg}^{-1} \mathrm{yr}^{-1}\end{array}$ & & $\begin{array}{l}\text { (Cowen et al., } \\
\text { 2006; Froese \& } \\
\text { Pauly, 2011) }\end{array}$ & $\begin{array}{l}\text { Calibration parameter because info are } \\
\text { sparse, uncertain, and variable. As a } \\
\text { result, these values will remain the } \\
\text { same }\end{array}$ \\
\hline $1 \_U *$ & Urchin larval production & $\begin{array}{c}2 \times 10^{5}-4 \times 10^{5} \\
\mathrm{~kg}^{-1} \mathrm{yr}^{-1}\end{array}$ & & $\begin{array}{c}\text { (Levitan, 1988, } \\
\text { 1991) }\end{array}$ & $\begin{array}{l}\text { Calibration parameter because info are } \\
\text { sparse, uncertain, and variable. As a } \\
\text { result, these values will remain the } \\
\text { same }\end{array}$ \\
\hline dlarv_Cb & $\begin{array}{l}\text { Initial mortality of brooded coral } \\
\text { lavae }\end{array}$ & $0.6-0.99$ & & (Fadlallah, 1983) & QE565.C68 Vol 2 p.129 - 150 \\
\hline drec_C & $\begin{array}{l}\text { Mortality of brooding and } \\
\text { spawning coral recruits during } \\
\text { the first year following } \\
\text { settlement }\end{array}$ & $0.2-0.7 \mathrm{yr}^{-1}$ & Range & (Babcock, 1985) & $\begin{array}{l}\text { Assumes that brooded larvae are } \\
\text { competent to settle within an average } \\
\text { period of four days (Fadlallah, 1983) } \\
\text { and that average pre-settlement } \\
\text { mortality is between } 0.2 \text { day }^{-1} \text { and } 0.7 \\
\text { day }^{-1} \text { (as for post-settlement mortality } \\
\text { of coral larvae). Pre-settlement } \\
\text { mortality is implicit in connectivity }\end{array}$ \\
\hline
\end{tabular}




\begin{tabular}{|c|c|c|c|c|c|}
\hline & & & & & $\begin{array}{l}\text { matrices for spawned coral, and urchin } \\
\text { larvae. }\end{array}$ \\
\hline drec_F & $\begin{array}{l}\text { Mortality of fish recruits during } \\
\text { the first year following } \\
\text { settlement }\end{array}$ & $0.2 \mathrm{yr}^{-1}$ & minimum & $\begin{array}{l}\text { (Beukers \& Jones, } \\
\text { 1997; Doherty \& } \\
\text { Fowler, 1994) }\end{array}$ & Lowest mortality rate reported \\
\hline drec_U & $\begin{array}{l}\text { Mortality of urchin recruits } \\
\text { during the first year following } \\
\text { settlement }\end{array}$ & $0.11-0.32 \mathrm{yr}^{-1}$ & range & $\begin{array}{l}\text { (Beukers \& Jones, } \\
\text { 1997; Doherty \& } \\
\text { Fowler, 1994) }\end{array}$ & $\begin{array}{l}\text { Ebert (2013), edited by Lawrence, Sea } \\
\text { Urchins: Biology and Ecology } 38\end{array}$ \\
\hline arec_C & $\begin{array}{l}\text { The area of } 1 \text { yr old coral } \\
\text { recruits }\end{array}$ & $2.18 \mathrm{~cm}^{2}$ & $\begin{array}{l}\text { point } \\
\text { estimate }\end{array}$ & (Edmunds, 2007) & $\begin{array}{l}\text { Assumes all recruits are } \sim 16.5 \mathrm{~mm} \\
\text { diameter or } 14.7 \mathrm{~mm} \text { on a side of a } \\
\text { square }\end{array}$ \\
\hline brec_H & $\begin{array}{l}\text { The biomass of } 1 \text { yr old } \\
\text { herbivorous recruits }\end{array}$ & $80 \mathrm{~g}$ & $\begin{array}{c}\text { point } \\
\text { estimate }\end{array}$ & $\begin{array}{c}\text { (Froese \& Pauly, } \\
\text { 2011) }\end{array}$ & \\
\hline brec_P & $\begin{array}{l}\text { The biomass of } 1 \text { yr old } \\
\text { piscivorous fish recruits }\end{array}$ & $150 \mathrm{~g}$ & $\begin{array}{c}\text { point } \\
\text { estimate }\end{array}$ & $\begin{array}{c}\text { (Froese \& Pauly, } \\
\text { 2011) }\end{array}$ & \\
\hline brec_U & $\begin{array}{l}\text { The biomass of } 1 \text { yr old urchin } \\
\text { recruits }\end{array}$ & $10 \mathrm{~g}$ & $\begin{array}{c}\text { point } \\
\text { estimate }\end{array}$ & $\begin{array}{l}\text { (R. Carpenter, } \\
\text { 1997; Levitan, } \\
\text { 1988) }\end{array}$ & \\
\hline
\end{tabular}


37 Table A3. Fishing Pressure across the Main Hawaiian Islands, 1965 - 2015

38 These values are an estimated linear increase of $\sim 24 \%$ across four subregions of the MHI, Kauai-

39 Niihau, O'ahu, Maui Nui, and the Big Island of Hawai'i. The values indicate fishing pressure, in

$40 \mathrm{~kg} \times 10^{3} \mathrm{~km}^{-2} \mathrm{yr}^{-1}$, for each (Dirk Zeller, Booth, Craig, \& Pauly, 2006)of 50 years from 1965 -

41 present. Historical commercial fishing pressure (Pooley 1993) was incorporated to a hind-cast

42 using 1980 recreational catch estimates (Pooley 1993), scaled to the HI state population (US

43 Census). Total catch was apportioned across subregions using present-day percent-of-total catch

44 from Hawaii Department of Aquatic Resources commercial fisheries reporting (2003 - 2011).

45 This per-capita interpolation method is a desirable alternative to the unsatisfactory method of 46 assuming "zero catch" for years wherein data is absent(D Zeller, Froese, \& Pauly, 2005; Dirk 47 Zeller et al., 2006).

\begin{tabular}{|c|c|c|c|c|}
\hline Fishing Area $\left(\mathrm{km}^{2}\right)$ & $\begin{array}{c}\text { Kaua'i - Ni'ihau } \\
1036\end{array}$ & $\begin{array}{c}\text { Sub } \\
\text { O'ahu } \\
992\end{array}$ & $\begin{array}{c}\text { Maui Nui } \\
1868\end{array}$ & $\begin{array}{c}\text { Hawai'i } \\
1500\end{array}$ \\
\hline Year & \multicolumn{4}{|c|}{ Fishing Pressure, $\mathrm{kg} \times 10^{3} \mathrm{~km}^{-2} \mathrm{yr}^{-1}$} \\
\hline 1965 & 495 & 5156 & 699 & 1013 \\
\hline 1966 & 498 & 5187 & 705 & 1023 \\
\hline 1967 & 501 & 5219 & 711 & 1032 \\
\hline 1968 & 504 & 5250 & 717 & 1042 \\
\hline 1969 & 507 & 5282 & 723 & 1052 \\
\hline 1970 & 510 & 5313 & 729 & 1062 \\
\hline 1971 & 513 & 5345 & 735 & 1071 \\
\hline 1972 & 516 & 5376 & 741 & 1081 \\
\hline 1973 & 519 & 5408 & 747 & 1091 \\
\hline 1974 & 522 & 5439 & 753 & 1101 \\
\hline 1975 & 525 & 5471 & 759 & 1110 \\
\hline 1976 & 528 & 5502 & 765 & 1120 \\
\hline 1977 & 531 & 5534 & 771 & 1130 \\
\hline 1978 & 534 & 5566 & 777 & 1140 \\
\hline 1979 & 537 & 5597 & 783 & 1149 \\
\hline 1980 & 540 & 5629 & 789 & 1159 \\
\hline 1981 & 543 & 5660 & 795 & 1169 \\
\hline 1982 & 546 & 5692 & 801 & 1179 \\
\hline 1983 & 550 & 5723 & 807 & 1188 \\
\hline
\end{tabular}




$\begin{array}{lllll}1984 & 553 & 5755 & 813 & 1198 \\ 1985 & 556 & 5786 & 819 & 1208 \\ 1986 & 559 & 5818 & 825 & 1218 \\ 1987 & 562 & 5849 & 831 & 1227 \\ 1988 & 565 & 5881 & 837 & 1237 \\ 1989 & 568 & 5912 & 843 & 1247 \\ 1990 & 571 & 5944 & 850 & 1257 \\ 1991 & 574 & 5975 & 856 & 1266 \\ 1992 & 577 & 6007 & 862 & 1276 \\ 1993 & 580 & 6038 & 868 & 1286 \\ 1994 & 583 & 6070 & 874 & 1295 \\ 1995 & 586 & 6101 & 880 & 1305 \\ 1996 & 589 & 6133 & 886 & 1315 \\ 1997 & 592 & 6165 & 892 & 1325 \\ 1998 & 595 & 6196 & 898 & 1334 \\ 1999 & 598 & 6228 & 904 & 1344 \\ 2000 & 601 & 6259 & 910 & 1354 \\ 2001 & 604 & 6291 & 916 & 1364 \\ 2002 & 607 & 6322 & 922 & 1373 \\ 2003 & 610 & 6354 & 928 & 1383 \\ 2004 & 613 & 6385 & 934 & 1393 \\ 2005 & 616 & 6417 & 940 & 1403 \\ 2006 & 619 & 6448 & 946 & 1412 \\ 2007 & 622 & 6480 & 952 & 1422 \\ 2008 & 625 & 6511 & 958 & 1432 \\ 2009 & 628 & 6543 & 964 & 1442 \\ 2010 & 631 & 6574 & 970 & 1451 \\ 2011 & 634 & 6606 & 976 & 1461 \\ 2012 & 637 & 6637 & 982 & 1481 \\ 2013 & 640 & 6669 & 988 & 1490 \\ 2014 & 643 & 6700 & 994 & \end{array}$


Appendix Reference List

Aliño, P. M., McManus, L. T., Mcmanus, J. W., Nafiola, C., Fortes, M. D., Trono G.C., \& Jacinto, G. S. (1993). Initial parameter estimations of a coral reef flat ecosystem in Bolinao, Pangasinan, northwestern Philippines. In ICLARM Conference Proceedings: Models of Aquatic Ecosystems (pp. 252-267).

Arias-González, J. E. (1998). Trophic models of protected and unprotected coral reef ecosystems in the South of the Mexican Caribbean. Journal of Fish Biology, 53(sa), 236-255. http://doi.org/10.1111/j.1095-8649.1998.tb01030.x

Arias-González, J. E., \& Morand, S. (2006). Trophic functioning with parasites: A new insight for ecosystem analysis. Marine Ecology Progress Series, 320, 43-53. http://doi.org/10.3354/meps320043

Babcock, R. C. (1985). Growth and mortality in juvenile corals (Goniastrea, Platygyra and Acropora) in the first year. Proceedings of the 5th International Coral Reef Symposium.

Bellwood, D. R., Hughes, T. P., Folke, C., \& Nyström, M. (2004). Confronting the coral reef crisis. Nature, 429(6994), 827-833. http://doi.org/10.1038/nature02691

Bellwood, D. R., Hughes, T. P., \& Hoey, A. S. (2006). Sleeping Functional Group Drives CoralReef Recovery. Current Biology, 16(24), 2434-2439. http://doi.org/10.1016/j.cub.2006.10.030

Beukers, J. S., \& Jones, G. P. (1997). Habitat complexity modifes the impact of piscivores on a coral reef fish population. Oecologia, 114, 50-59. http://doi.org/10.1007/s004420050419

Birrell, C. L., McCook, L. J., \& Willis, B. L. (2005). Effects of algal turfs and sediment on coral 
settlement. Marine Pollution Bulletin, 51(1-4), 408-414.

http://doi.org/10.1016/j.marpolbul.2004.10.022

Birrell, C. L., McCook, L. J., Willis, B. L., \& Harrington, L. (2008). Chemical effects of macroalgae on larval settlement of the broadcast spawning coral Acropora millepora. Marine Ecology Progress Series, 362, 129-137. http://doi.org/10.3354/meps07524

Box, S. J., \& Mumby, P. J. (2007). Effect of macroalgal competition on growth and survival of juvenile Caribbean corals. Marine Ecology Progress Series, 342, 139-149. http://doi.org/10.3354/meps342139

Bruno, J. F., \& Selig, E. R. (2007). Regional decline of coral cover in the Indo-Pacific: Timing, extent, and subregional comparisons. PLoS ONE, 2(8). http://doi.org/10.1371/journal.pone.0000711

Bythell, J. C., Gladfelter, E. H., \& Bythell, M. (1993). Chronic and catastrophic natural mortality of three common Caribbean reef corals. Coral Reefs, 12(3-4), 143-152. http://doi.org/10.1007/BF00334474

Carpenter, R. (1997). Invertebrate predators and grazers. Life and Death of Coral Reefs. Chapman and Hall, ..., 1-43. Retrieved from http://www.marine.usf.edu/reefslab/documents/evol_ecol2007/Carpenter(inpress).pdf

Carpenter, R. C. (1986). Partitioning Herbivory and Its Effects on Coral Reef Algal Communities. Ecological Monographs, 56(4), 345-364. http://doi.org/10.2307/1942551

Carpenter, R. C. (1990). Mass mortality of Diadema antillarum II. Effects on population densities and grazing intensity of parrotfishes and surgeonfishes. Marine Biology, 104, 79- 
86. Retrieved from file://C:/MichFish/Journal Articles/Carpenter MarBio 1990_II.pdf

92

Carpenter, S. R., Kitchell, J. F., \& Hodgson, J. R. (1985). Fish predation and herbivory can regulate lake ecosystems. BioScience, 35(10), 634-639. http://doi.org/10.2307/1309989

Chornesky, E. A., \& Peters, E. C. (1987). Sexual reproduction and colony growth in the scleractinian coral Porites astreoides. Biological Bulletin, 172, 161-177.

Cowen, R. K., Paris, C. B., \& Srinivasan, A. (2006). Scaling of connectivity in marine populations. Science (New York, N.Y.), 311(5760), 522-527. http://doi.org/10.1126/science.1122039

Coyne, M. S., Battista, T., Anderson, M., Wadell, J., Smith, W., Jokiel, P. L., .. Monaco, M. E. (2003). Benthic Habitats of the Main Hawaiian Islands URL : http://biogeo.nos.noaa.gov/projects/mapping/pacific. Also available on U. S. National Oceanic and Atmospheric Administration. National Ocean Service, National Centers for Coastal Ocean Science, Biogeogra.

Craig, P., Green, a G., \& Tuilagi, F. (2008). Subsistence harvest of coral reef resources in the outer islands of American Samoa: Modern, historic and prehistoric catches. Fisheries Research, 89(3), 230-240. http://doi.org/10.1016/j.fishres.2007.08.018

De Ruyter van Steveninck, E. D., Van Mulekom, L. L., \& Breeman, a. M. (1988). Growth inhibition of Lobophora variegata (Lamouroux) Womersley by scleractinian corals. Journal of Experimental Marine Biology and Ecology, 115(2), 169-178. http://doi.org/10.1016/0022-0981(88)90101-3

Diaz-Pulido, G., \& McCook, L. J. (2004). Effects of live coral, epilithic algal communities and 
112

113

114

115

116

117

118

119

120

121

122

123

124

125

126

127

128

129

130

131

132

substrate type on algal recruitment. Coral Reefs, 23(2), 225-233.

Doherty, P., \& Fowler, T. (1994). An Empirical Test of Recruitment Limitation in a Coral Reef Fish. Science. http://doi.org/10.1126/science.263.5149.935

Ebert, T. A. (1975). Growth and Mortality of Post-larval Echinoids. American Zoologist, 15, 755-775. http://doi.org/10.1093/icb/15.3.755

Edmunds, P. J. (2007). Evidence for a decadal-scale decline in the growth rates of juvenile scleractinian corals. Marine Ecology Progress Series, 341, 1-13. http://doi.org/10.3354/meps341001

Edwards, C. B., Friedlander, A. M., Green, a G., Hardt, M. J., Sala, E., Sweatman, H. P., ... Smith, J. E. (2014). Global assessment of the status of coral reef herbivorous fishes : evidence for fishing effects, 7-11.

Fadlallah, Y. H. (1983). Sexual Reproduction, Development in Scleractinian Corals. Coral Reefs, 2, 129-150.

Friedlander, A. M., Aeby, G., Brainard, R. E., Brown, E. K., Chaston, K., Clark, A., ... Wiltse, W. (2008). The state of coral reef ecosystems of the Main Hawaiian Islands. The State of Coral Reef Ecosystems of the United States and Pacific Freely Associated States: 2008, 219-253.

Friedlander, A. M., \& DeMartini, E. E. (2002). Contrasts in density, size, and biomass of reef fishes between the northwestern and the main Hawaiian islands: The effects of fishing down apex predators. Marine Ecology Progress Series, 230, 253-264.

http://doi.org/10.3354/meps230253 
133 Froese, R., \& Pauly, D. (2011). Fishbase. Retrieved from www.fishbase.org

134 Fung, T. (2009). Local scale models of coral reef ecosystems for scenario testing and decision

135

136

137

138

139

140

141

142

143

144

145

146

147

148

149

150

151

152

153 support.

Garcia-Salgado, M., \& Nava-Martinez, G. (2008). Status of coral reefs in the Mesoamerican region. Status of Coral Reefs of the ..., 253-264. Retrieved from http://scholar.google.com/scholar?hl=en\&btnG=Search\&q=intitle:Status + of + Coral + Reefs $+\mathrm{i}$ $\mathrm{n}+$ the+Mesoamerican+Region\#4\nhttp://scholar.google.com/scholar?hl=en\&btnG=Search\& $\mathrm{q}=$ intitle:Status + of + coral + reefs + in + the + Mesoamerican + region $\# 4$

Gardner, T. a., Côté, I. M., Gill, J. a., Grant, A., \& Watkinson, A. R. (2005). Hurricanes and caribbean coral reefs: Impacts, recovery patterns, and role in long-term decline. Ecology, 86, 174-184. http://doi.org/10.1890/04-0141

Gribble, N. a. (2003). GBR-prawn: Modelling ecosystem impacts of changes in fisheries management of the commercial prawn (shrimp) trawl fishery in the far northern Great Barrier Reef. Fisheries Research, 65(1-3), 493-506. http://doi.org/10.1016/j.fishres.2003.09.035

Harrison, P. L., \& Wallace, C. C. (1990). Reproduction, dispersal and recruitment of scleractinian corals. Coral Reefs. Ecosystems of the World (Vol. 25).

Hay, M. E. (1984). Patterns of fish and urchin grazing on Caribbean coral reefs: are previous results typical? Ecology. http://doi.org/10.2307/1941407

Hay, M. E. (1991). Marine-terrestrial contrasts in the ecology of plant chemical defenses against herbivores. Trends in Ecology and Evolution, 6(11), 362-365. http://doi.org/10.1016/0169- 
154 155 156 157 158 159 160 161 162 163 164 165 166 167 168 169 170 171 172 173 174

5347(91)90227-O

Hughes, T. P., Rodrigues, M. J., Bellwood, D. R., Ceccarelli, D., Hoegh-Guldberg, O., McCook, L. J., ... Willis, B. (2007). Phase Shifts, Herbivory, and the Resilience of Coral Reefs to Climate Change. Current Biology, 17(4), 360-365. http://doi.org/10.1016/j.cub.2006.12.049

Huston, M. (1985). Variation in coral growth rates with depth at Discovery Bay, Jamaica. Coral Reefs, 4, 19-25. http://doi.org/10.1007/BF00302200

Johnson, C., Klumpp, D. W., Field, J., \& Bradbury, R. (1995). CARBON FLUX ON CORALREEFS - EFFECTS OF LARGE SHIFTS IN COMMUNITY STRUCTURE. Marine Ecology Progress Series, 126(1-3), 123-143. http://doi.org/10.3354/meps 126123

Jompa, J., \& McCook, L. J. (2002). The effects of nutrients and herbivory on competition between a hard coral (Porites cylindrica) and a brown alga (Lobophora variegata). Limnology and Oceanography, 47(2), 527-534. http://doi.org/10.4319/lo.2002.47.2.0527

Jompa, J., \& McCook, L. J. (2003). Coral-algal competition: Macroalgae with different properties have different effects on corals. Marine Ecology Progress Series, 258, 87-95. http://doi.org/10.3354/meps258087

Koop, K., Booth, D. J., Broadbent, a., Brodie, J., Bucher, D., Capone, D., ... Yellowlees, D. (2001). ENCORE: The effect of nutrient enrichment on coral reefs. Synthesis of results and conclusions. Marine Pollution Bulletin, 42(2), 91-120. http://doi.org/10.1016/S0025$326 \mathrm{X}(00) 00181-8$

Kramer, D. B. (2008). Adaptive Harvesting in a Multiple-Species Coral-Reef Food Web. Ecology And Society, 13(1), 17. http://doi.org/17 
175 Kramer, P. a. (2003). Synthesis of coral reef health indicators for the western Atlantic: Results of 176 the AGRRA program (1997-2000). Atoll Research Bulletin, 1-57. http://doi.org/10.5479/si.00775630.496-3.1

178 179 180 181 182 183 184 185 186 187 188 189 190 191 192 193 194 195

Langmead, O., \& Sheppard, C. (2004). Coral reef community dynamics and disturbance: A simulation model. Ecological Modelling, 175(3), 271-290. http://doi.org/10.1016/j.ecolmodel.2003.10.019

Lapointe, B. E. (1989). Macroalgal production and nutrient relations in oligotrophic areas of Florida Bay. Bulletin of Marine Science.

Larned, S. T. (1998). Nitrogen- versus phosphorus-limited growth and sources of nutrients for coral reef macroalgae. Marine Biology, 132(3), 409-421. http://doi.org/10.1007/s002270050407

Letourneur, Y., Kulbicki, M., \& Labrosse, P. (1998). Report: Spatial structure of commercial reef fish communities along a terrestrial runoff gradient in the northern lagoon of New Caledonia. Environmental Biology of Fishes, 51(2), 141-159. http://doi.org/10.1023/A:1007489502060

Levitan, D. R. (1988). Algal-urchin biomass responses following mass mortality of Diadema antillarum Philippi at Saint John, U.S. Virgin Islands. Journal of Experimental Marine Biology and Ecology, 119(2), 167-178. http://doi.org/10.1016/0022-0981(88)90231-6

Levitan, D. R. (1991). Influence of Body Size and Population Density on Fertilization Success and Reproductive Output in a Free-Spawning Invertebrate. Biol. Bull., 181(June), 261-268. http://doi.org/10.2307/1542097 
196 197 198 199 200 201 202 203 204 205 206 207 208 209 210

Lirman, D. (2001). Competition between macroalgae and corals: Effects of herbivore exclusion and increased algal biomass on coral survivorship and growth. Coral Reefs, 19(4), 392-399. http://doi.org/10.1007/s003380000125

Lirman, D. (2003). A simulation model of the population dynamics of the branching coral Acropora palmata Effects of storm intensity and frequency. Ecological Modelling, 161, 169-182.

Loya, Y., Lubinevsky, H., Rosenfeld, M., \& Kramarsky-Winter, E. (2004). Nutrient enrichment caused by in situ fish farms at Eilat, Red Sea is detrimental to coral reproduction. Marine Pollution Bulletin, 49(4), 344-353. http://doi.org/10.1016/j.marpolbul.2004.06.011

Mangi, S. C., \& Roberts, C. M. (2007). Factors influencing fish catch levels on Kenya's coral reefs. Fisheries Management and Ecology, 14(4), 245-253. http://doi.org/10.1111/j.13652400.2007.00549.x

McClanahan, T. R. (1996). Fishery recovery in a coral-reef marine park and its effects on teh adjacent fishery. Conservation Biology, 10(4), 1187-1199. http://doi.org/10.1046/j.15231739.1996.10041187.x

McClanahan, T. R., Kamukuru, a. T., Muthiga, N. a., Yebio, M. G., \& Obura, D. (1996). Effect of Sea Urchin Reductions on Algae, Coral, and Fish Populations. Conservation Biology, 10(1), 136-154. http://doi.org/10.1046/j.1523-1739.1996.10010136.x

McClanahan, T. R., Polunin, N., \& Done, T. (2002). Ecological states and the resilience of coral reefs. Ecology and Society, 6(2).

McCook, L. J. (1999). Macroalgae, nutrients and phase shifts on coral reefs: Scientific issues and 
management consequences for the Great Barrier Reef. Coral Reefs, 18(4), 357-367. http://doi.org/10.1007/s003380050213

McCook, L. J., Jompa, J., \& Diaz-Pulido, G. (2001). Competition between corals and algae on coral reefs: A review of evidence and mechanisms. Coral Reefs, 19(4), 400-417. http://doi.org/10.1007/s003380000129

Mumby, P. J., Dahlgren, C. P., Harborne, A. R., Kappel, C. V, Micheli, F., Brumbaugh, D. R., ... Gill, A. B. (2006). Fishing, Trophic Cascades, and the Process of Grazing on Coral Reefs. Science, 311(5757), 98-101. http://doi.org/10.1126/science.1121129

Mumby, P. J., Dahlgren, C. P., Harborne, A. R., Kappel, C. V, Micheli, F., Brumbaugh, D. R., ... Gill, A. B. (2006). Process of Grazing on Coral Reefs. Science, 311(5757), 98-101. http://doi.org/10.1126/science.1121129

Mumby, P. J., \& Dytham, C. (2006). Metapopulation Dynamics of Hard Corals. In Marine Metapopulations (pp. 157-203). http://doi.org/http://dx.doi.org/10.1016/B978-012088781$1 / 50008-\mathrm{X}$

Mumby, P. J., Foster, N. L., \& Fahy, E. a G. (2005). Patch dynamics of coral reef macroalgae under chronic and acute disturbance. Coral Reefs, 24(4), 681-692. http://doi.org/10.1007/s00338-005-0058-5

Newman, M. J. H., Paredes, G. a., Sala, E., \& Jackson, J. B. C. (2006). Structure of Caribbean coral reef communities across a large gradient of fish biomass. Ecology Letters, $9(11)$, 1216-1227. http://doi.org/10.1111/j.1461-0248.2006.00976.x

Nugues, M. M., \& Bak, R. P. M. (2006). Differential competitive abilities between Caribbean 
coral species and a brown alga: A year of experiments and a long-term perspective. Marine Ecology Progress Series, 315, 75-86. http://doi.org/10.3354/meps315075

Nugues, M. M., \& Roberts, C. M. (2003). Coral mortality and interaction with algae in relation to sedimentation. In Coral Reefs (Vol. 22, pp. 507-516). http://doi.org/10.1007/s00338-0030338-x

Nugues, M. M., \& Szmant, A. M. (2006). Coral settlement onto Halimeda opuntia: A fatal attraction to an ephemeral substrate? Coral Reefs, 25(4), 585-591. http://doi.org/10.1007/s00338-006-0147-0

Randall, J. E., Schroeder, R. E., \& Starck II, W. a. (1964). Notes on the biology of the Echinoid Diadema antillarum. Caribbean Journal of Science, 4, 421-433. http://doi.org/10.1126/science.1.10.263

Richmond, R. H. (1988). Competency and dispersal potential of planula larvae of a spawning versus a brooding coral. Proceedings of the 6th International Coral Reef Symposium, 2, 827-831.

Rodgers, K. S., Jokiel, P. L., Brown, E. K., Hau, S., \& Sparks, R. (2015). Over a Decade of Change in Spatial and Temporal Dynamics of Hawaiian Coral Reef Communities. Pacific Science, 69(1), 1-13. http://doi.org/10.2984/69.1.1

Russ, G. R. (2003). Grazer biomass correlates more strongly with production than with biomass of algal turfs on a coral reef. Coral Reefs, 22(1), 63-67. http://doi.org/10.1007/s00338-0030286-5

Russ, G. R., \& St. John, J. (1988). Diets, growth rates and secondary production of herbivorous 
coral reef fishes. In Proceedings of the 6th International Coral Reef Symposium (pp. 3743).

Sandin, S. A., Smith, J. E., DeMartini, E. E., Dinsdale, E. A., Donner, S. D., Friedlander, A. M., ... Sala, E. (2008). Baselines and Degradation of Coral Reefs in the Northern Line Islands. PLoS ONE, 3(2), e1548. http://doi.org/10.1371/journal.pone.0001548

Stimson, J., Larned, S. T., \& Conklin, E. (2001). Effects of herbivory, nutrient levels, and introduced algae on the distribution and abundance of the invasive macroalga Dictyosphaeria cavernosa in Kaneohe Bay, Hawaii. CORAL REEFS, 19(4), 343-357. http://doi.org/10.1007/s003380000123

Tsehaye, I., \& Nagelkerke, L. a J. (2008). Exploring optimal fishing scenarios for the multispecies artisanal fisheries of Eritrea using a trophic model. Ecological Modelling, 212(3-4), 319-333. http://doi.org/10.1016/j.ecolmodel.2007.10.044

Van Rooij, J. M., Videler, J. J., \& Bruggemann, J. H. (1998). High biomass and production but low energy transfer efficiency of Caribbean parrotfish: implications for trophic models of coral reefs. Journal of Fish Biology, 53(2442), 154-178. http://doi.org/10.1006/jfbi.1998.0831

Ward, S., \& Harrison, P. L. (2000). Changes in gametogenesis and fecundity of acroporid corals that were exposed to elevated nitrogen and phosphorus during the ENCORE experiment. Journal of Experimental Marine Biology and Ecology, 246(2), 179-221. http://doi.org/10.1016/S0022-0981(99)00182-3

Williams, D. M., \& Hatcher, A. I. (1983). Structure of Fish Communities on Outer Slopes of Inshore, Mid-Shelf and Outer Shelf Reefs of the Great Barrier Reef. Marine Ecology 
281 Progress Series, 10, 239-250. http://doi.org/10.3354/meps010239

282 Zeller, D., Booth, S., Craig, P., \& Pauly, D. (2006). Reconstruction of coral reef fisheries catches 283 in American Samoa, 1950-2002. In Coral Reefs (Vol. 25, pp. 144-152).

284 http://doi.org/10.1007/s00338-005-0067-4

285 Zeller, D., Froese, R., \& Pauly, D. (2005). On losing and recovering fisheries and marine science 286 data. Marine Policy, 29, 69-73. http://doi.org/10.1016/j.marpol.2004.02.003 


\section{IMPLEMENTATION}

\begin{tabular}{ll}
\hline CORAL & $\begin{array}{l}\text { Coral bleaching events were simulated via the "coral mortality" forcing term, with the years and } \\
\text { BLEACHING }\end{array}$ \\
& $\begin{array}{l}\text { proportional mortalities of specific bleaching events specified by the user and occurring } \\
\text { mortality) from bleaching events were randomly selected from a uniform distribution of range }\end{array}$ \\
& $0.05-0.15$.
\end{tabular}

Table S1. Summary of forcing implementations used in CORSET. 
MODELED DOMAIN $\left(\mathrm{KM}^{2}\right)$

Spatial extent of modeled reef cells

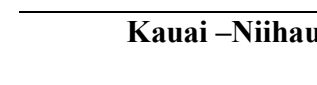

Oahu

Maui Nui

Hawaii

1440

3184

2912

Estimated Values \pm standard error

\begin{tabular}{|c|c|c|c|c|c|c|}
\hline \multirow{9}{*}{ 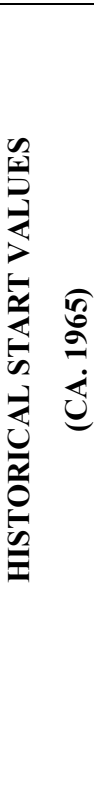 } & Mean Coral Cover & Average $\%$ cover & $4.65 \pm 1.86$ & $14.28 \pm 1.32$ & $23.56 \pm 2.44$ & $29.52 \pm 1.08$ \\
\hline & $\mathrm{Cb}$ & brooding corals, mean \% cover ca. 1965 & 1.16 & 3.57 & 5.89 & 7.38 \\
\hline & Cs & spawning corals, mean \% cover ca. 1965 & 3.49 & 10.71 & 17.67 & 22.14 \\
\hline & $\mathrm{T}$ & Mean $\%$ cover of turf algae & 61.2 & 22 & 7 & 17 \\
\hline & M & Mean $\%$ cover of macro algae & 5 & 12 & 11.5 & $<2$ \\
\hline & $\mathrm{H}$ & herbivorous fish, $\mathrm{kg} \mathrm{km}^{-2}$ & & & 31700 & \\
\hline & Ps & small piscivores, $\mathrm{kg} \mathrm{km}^{-2}$ & & & 1800 & \\
\hline & $\mathrm{Pl}$ & large piscivores, $\mathrm{kg} \mathrm{km}^{-2}$ & & & 1800 & \\
\hline & U & Urchins, $\mathrm{kg}^{3} \mathrm{~km}^{-2}$ & & & 2100 & \\
\hline
\end{tabular}

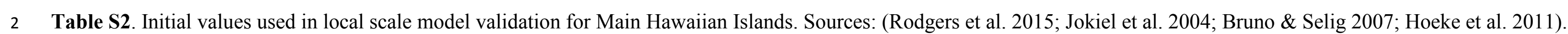




\section{Detailed Methods of Main Hawaiian Islands CORSET Instantiation}

\section{CORSET Structure}

The CORSET model is comprised of four components: local ecology, larval connectivity, and anthropogenic and environmental forcings (Figure 1). CORSET uses a 'functional group' approach to model interactions between two types of corals (brooding and broadcast spawning species), two types of algae (macroalgae, and turf algae), herbivorous fish, small-to-intermediate sized piscivorous fish, large piscivorous fish, and sea urchins. Turf algae, which is termed 'macroturf' in CORSET's original documentation, refers to algal turfs with height greater than 24mm. Parameters that describe local-scale ecological processes are selected at random from predefined, uniform ranges derived from empirical observations. The local-scale ecological model used in CORSET is a mean-field model that describes average interactions between benthic and consumer functional groups, which are coupled across subregions by larval dispersal. This structure renders CORSET as stochastic, with the inclusion of natural disturbances such as hurricane, disease, bleaching events, and direct human impacts (nutrification, fishing, and sedimentation). A summary of forcing implementations for human, environmental and physical forcings is found in Table S1.

\section{Model Development and Validation}

We developed a gridded basemap (Figure 2A,B) consisting of four subregions: Kaua'i Ni'ihau; O'ahu, Maui Nui, and Hawai'i, also known as the Big Island. The spatial extent of this instantiation was $3,263,632 \mathrm{~km}^{2}$ and a total reef area of $1,342 \mathrm{~km}^{2}$ was modeled. Geographicallydesignated subregions are ideal for organizing management efforts; there is additional genetic evidence that suggests these regions represent shared genetic population breaks (Eble et al. 
2011). Subregional designation has no bearing on the behavior of the model; they are simply organizational units for forcing activities. The domain was represented in two resolutions: $2 \mathrm{~km} \mathrm{x}$ $2 \mathrm{~km}$, and $4 \mathrm{~km} \times 4 \mathrm{~km}$. The $4 \mathrm{~km} \times 4 \mathrm{~km}$ resolution was used for the all validation and sensitivity procedures. See supplemental material for details of the sensitivity analysis.

We simulated benthic covers of coral and algae, and the biomasses of fish and urchins for a shallow $(5-20 \mathrm{~m})$ coral reef habitat in each reef cell using a discretized weekly time step. We model nine functional groups: brooding corals, spawning corals, turf algae, grazed epilithic algal communities (EAC), herbivorous fish, small-to-intermediate $(<60 \mathrm{~cm})$ piscivorous fish, large $(\geq$ $60 \mathrm{~cm})$ piscivorous fish, and sea urchins. Other benthic organisms such as soft corals, sponges, ascidians, and clams are assumed to make non-significant contributions to the dynamics we are attempting to capture and so are not modeled. Together, these organisms contribute to a proportional cover of benthic space. We have considered only those fish groups that are reefassociated. State variable inputs, in the form of .txt files, were modified based on empirical data gathered from field and remote-sensing studies throughout the Hawaiian Islands. In the absence of such data, range substitutions were made from previous instantiations' parameratizations, namely for the Indo-Pacific. A list of initial values, their description and sources are in Table 1; these are sourced predominantly from in-situ surveys within the main Hawaiian Islands (Rodgers et al. 2010). Empirical \% coral cover values were partitioned as $75 \%$ broadcast spawning corals (producing and releasing gametes over a broad geographic area), and 25\% brooding corals; historical percent cover was hind-cast to $20 \%$ greater than current values (Bruno \& Selig 2007). A detailed exploration of equilibrium behavior and parameter sensitivities for both the localscale, differential (continuous) system from which CORSET was derived, and the discrete-time equation array that constitutes the model used here, are each available in the Appendices. 
Hurricane events were not forced during the validation aspect of this study, as they have not been a strong ecological driver in this region (Dollar \& Tribble 1993; Dollar 1982), especially relative to Caribbean reefs (Dollar \& Grigg 2004; Ostrander et al. 2000; Vroom \& Timmers 2009; Gardner et al. 2005). Nutrification and sedimentation impacts were also not modeled as forcing events in checking for model accuracy.

We performed a model validation to test whether the calibrated model was able to produce stable long-term (100-year) trajectories in the absence of external forcings, and to examine accuracy of the model at matching observed community composition measures for the period from 1965 through 2010. For both procedures, we used initial values for benthic and consumer percent cover and biomass derived from empirical observations wherever possible.

To test whether the model could accurately reproduce observed values for current community composition when provided real world events, we gleaned a range of proportional mortality values from historical bleaching events within the Main Hawaiian Islands, which range from $5 \%$ to a maximum of $15 \%$-- the percentage indicating the proportional loss of coral cover attributable to a bleaching event alone (Hoeke et al. 2011; De'ath et al. 2012; Osborne et al. 2011). We validated the model using real-world bleaching events from the last five decades using this mortality range, which affected the entire MHI in 1996, 2014, and 2015. Additionally, best estimates for historical and current fishing pressure were incorporated into model runs as a linear increase in fishing pressure across all functional groups (Zeller et al. 2006). For validation procedures, present-day fishing catch was made accessible by the State of Hawai'i Department of Aquatic Resources, in tabular and spatial form. The data from 2003 - 2011 were subset for coastal $\left(<2 \mathrm{~nm}\right.$ from shore) fishing polygons, from which a fishing pressure parameter $\left(\mathrm{kg} \mathrm{km}^{-2}\right.$ $\mathrm{yr}^{-1}$ ) was calculated for each subregion (see Appendix). Historical commercial and recreational 
catch was estimated from prior reports (Pooley 1993). We modeled this as a linear, proportional sub-regional increase in fishing pressure (in $\mathrm{kg} \mathrm{km}^{-2}$ ) from 1965 - 2015; this method was suggested by Zeller et al. (2006) as a simple method for historical catch reconstruction. In all sensitivity analyses, fishing pressure was assigned a value of zero throughout the model run.

For robust comparision, we normalized empirical values from benthic and consumer reef survey data collected throughout the MHI over the last 15 years, considering that not all methods accounted for benthic cover or consumer biomass in the same way. Observations from the Coral Reef Assessment and Monitoring Program (Rodgers et al. 2010), which was conducted at over 40 fixed sites across the MHI, and diver survey data from NOAA's Coral Reef Ecosystem Division (CRED) both utilized visual estimation procedures that required benthic cover statevariables to sum to $100 \%$. Because CORSET does not allow the paramerization of open space, cyanobacteria nor 'other' living benthos, and the four modeled state variables must sum to $100 \%$, we re-categorized and normalized empirical data to match CORSET's requirements.

\section{Sensitivity Analysis}

Using our spatially-explicit, regional-scale biophysical model, we investigated several aspects of model sensitivity and behavior. The first two exercises, in identifying high leverage parameters and their effects on recovery trajectories, is a replication of the preliminary analyses performed by Melbourne-Thomas et al (2011) to investigate whether the MHI system behaved similarly to previous instantiations. We used reef community composition, visualized in multivariate space, as the response variable to forcing parameters. Principal Components Ordination (PCA) was performed using the vegan (Oksanen et al. 2013) package in the R statistical program (R Development Core Team 2011). In all sensitivity analyses, fishing pressure was assigned a value of zero throughout the model run. 


\section{Identifying High-Leverage Parameters}

We first investigated which parameters are higher-leverage by running three 100 -year simulations, with each parameter fixed at either its plausible maximum or minimum initial values, with all other parameters allowed to vary randomly within their range. For parameters that did not have a range, we fixed values at $\pm 10 \%$ of their given value(Mumby et al. 2006; Melbourne-Thomas et al. 2011). Under a 'null' case, all parameters were allowed to vary randomly within their ranges. We present the terminal reef state using normalized reef state data in principal ordination space. This approach allows for the full range of potential behaviors to be investigated, and replicates the default model behavior; however, synergistic effects of parameters on system dynamics cannot be quantified by this method.

\section{Induced Bleaching}

To provide direct comparison between published results and this instantiation, we also simulated a high-mortality (60\%) bleaching event across all subregions in year 2055 to evaluate the recovery capacity of the modeled system. We fixed the 10 highest-leverage parameters from the preceding analysis at each of their minimum and maximum values, with the supposition that these influential parameters may be similarly crucial in disturbance regimes. If shown to be the case, this approach justifies the direct manipulation of "high leverage" parameters in future, management-driven scenario tests.

\section{Spatial and Temporal Sensitivity}

The MHI instantiation of CORSET uses a gridded basemap with cell dimensions equal to $2 \mathrm{~km} \times 2 \mathrm{~km}$. Because local dynamics are coupled spatially via larval connectivity, the number of "occupied" reef cells - potential source/sink larval nodes - changes in tandem with basemap resolution. Therefore, [6] compared model behavior at resolutions of $0.5 \mathrm{~km}^{2}, 1 \mathrm{~km}^{2}, 2 \mathrm{~km}^{2}$ for the 
117 Meso-American Region, the same magnitude of difference as the Main Hawaiian Islands (1km x $1181 \mathrm{~km}, 2 \mathrm{~km} \times 2 \mathrm{~km}$, and $4 \mathrm{~km} \times 4 \mathrm{~km})$. That study found were no ecologically significant 119 differences found between spatial resolutions of the same magnitude difference as our 120 instantiation $\left(0.5 \mathrm{~km}^{2}, 1 \mathrm{~km}^{2}, 2 \mathrm{~km}^{2}\right.$ for the Meso-American Region). The CORSET model updates using a discrete time step. While output is reported on a 122 yearly basis, this updating interval is the rate at which ecological dynamics take place within the model. A small interval therefore approximates continuous models(Fung et al. 2011; Fung 2009).

124 This is mathematically advantageous as it requires fewer restraints to keep steady-state variables 125 within a realistic domain, though it can exponentially increase computational demand for model processing. For this analysis, in replication of (Melbourne-Thomas et al. 2011), we compared 127 model behavior under daily, weekly, fortnightly, monthly and yearly updating intervals. Models conducted under yearly and monthly updating intervals exited the biological domain (tending towards + infinity) in $100 \%$ of runs. Smaller intervals (daily, weekly, fortnightly) remained within the domain. Such behavior suggests there exists a tolerance threshold within the updating interval; overall trends in community composition at steady state were similar among the three 132 smaller intervals.

\section{High Leverage Parameters}

Results from the parameter sensitivity analysis, in which every parameters was fixed at either its maximum or minimum value and averaged across three 100 -year runs, are displayed in Figures S1-3. 
Principal Components Plot, Year 100 - Benthic Parameters

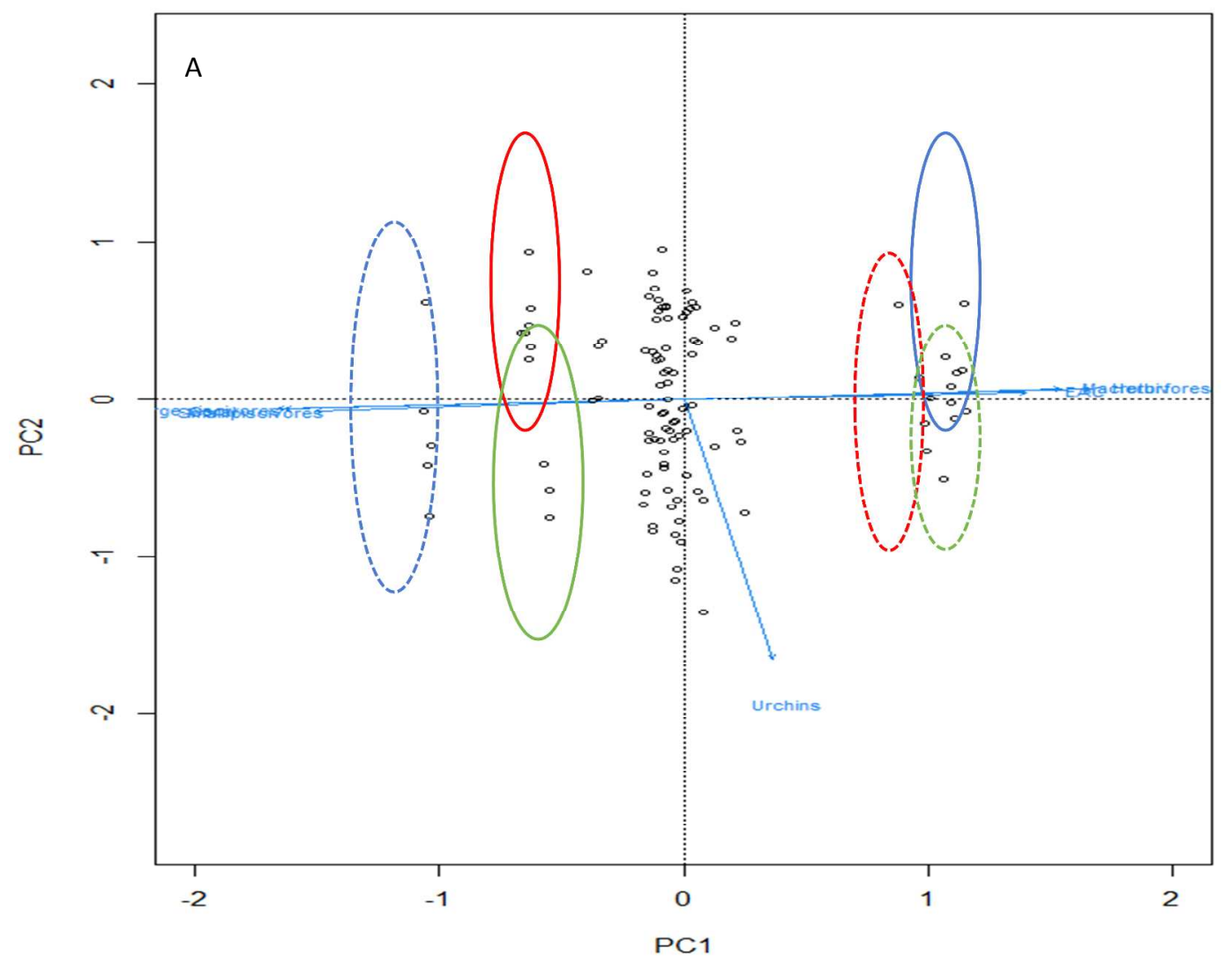

Principal Components Plot, Year 100 - Consumer Parameters

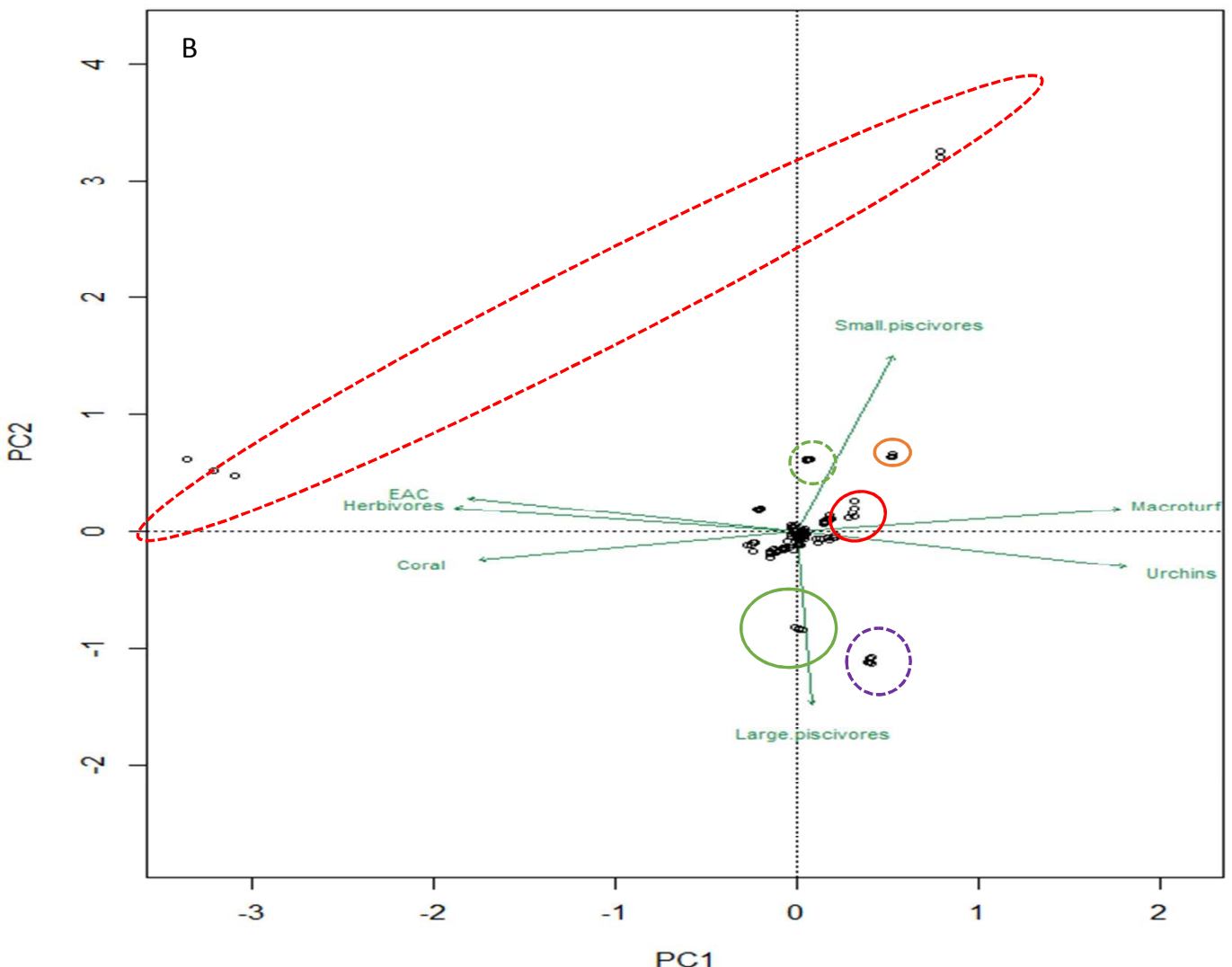

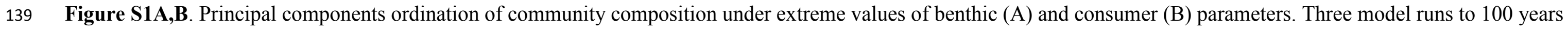
were averaged for each parameter fixed at its maximum or minimum value. Radiating lines indicate state variable vectors (eigenvectors). In (A), $89 \%$ of the total variance is

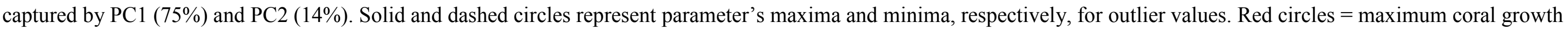




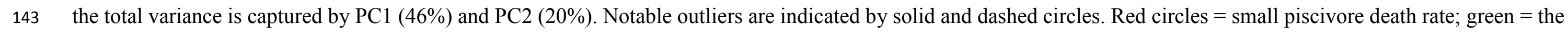

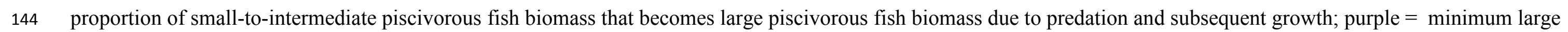

145 piscivore death rate; orange $=$ maximum herbivore death rate 
Principal Components Plot, Year 100 - Larval Parameters

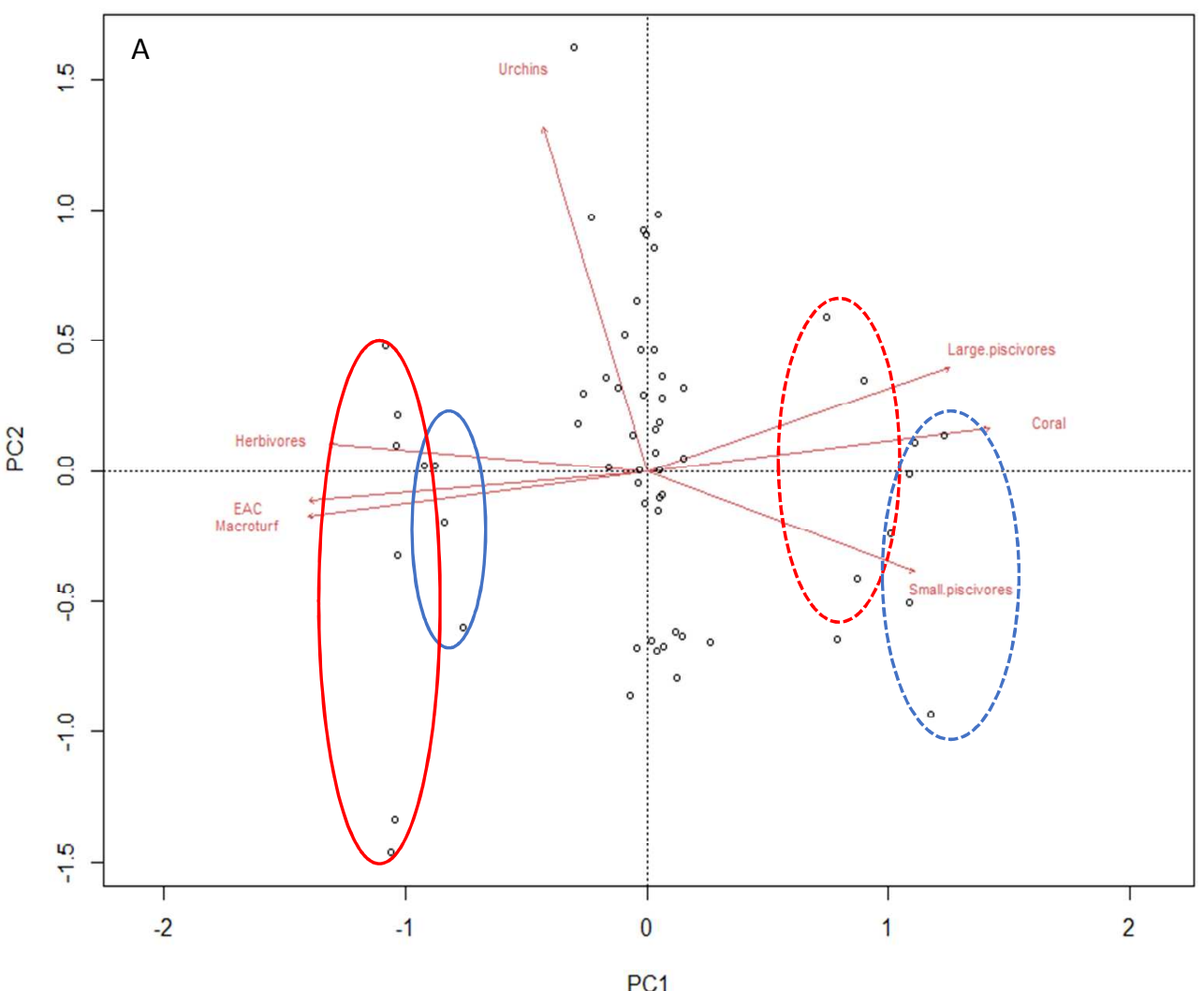

Principal Components Plot, Year 100 - Forcing Parameters

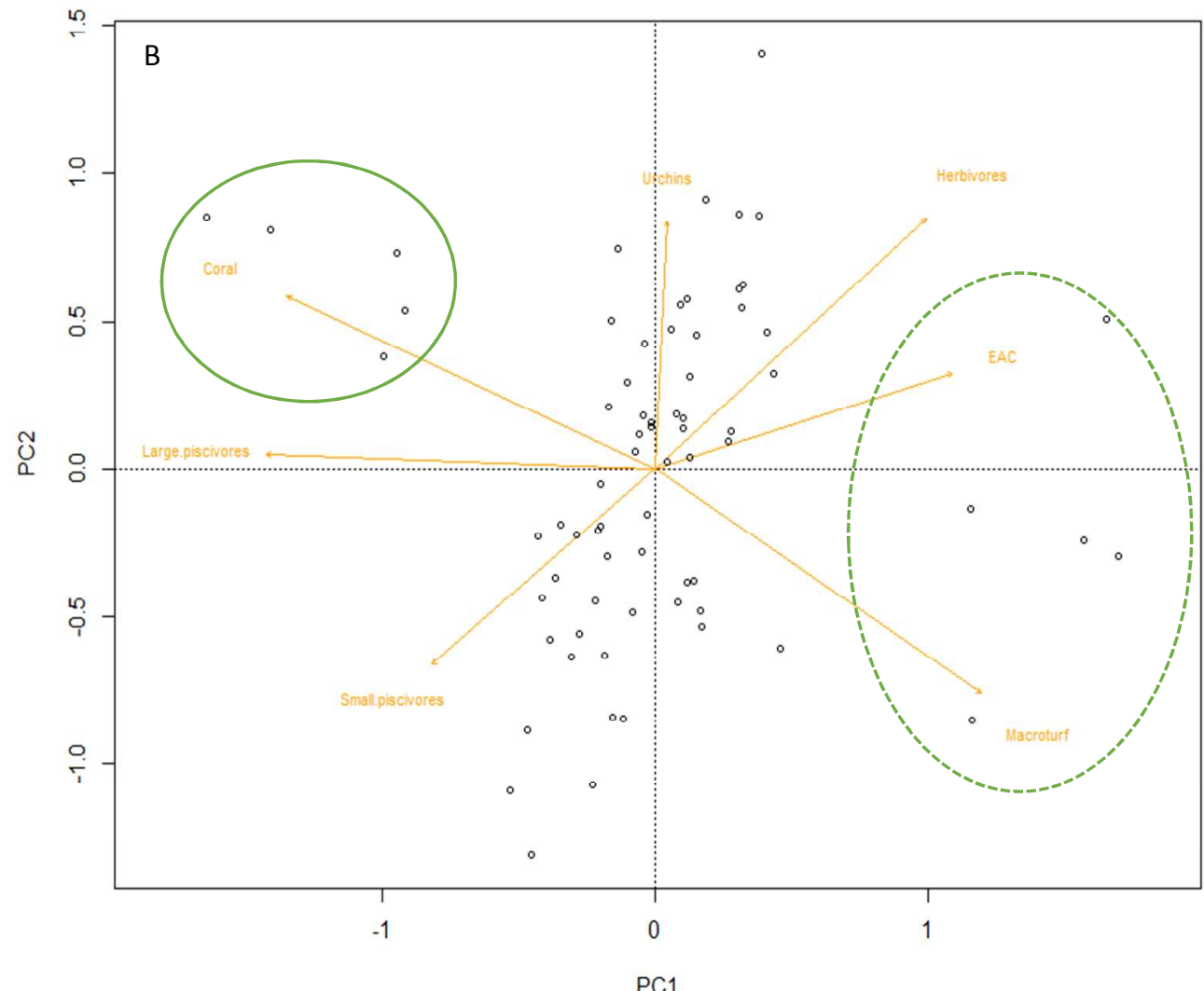

147

Figure S2A,B. Principal components ordination of extreme values of larval and forcing parameters. Solid and dashed lines represent parameter's maxima and minima, respectively. In (A), 86\% of the total variance is captured by PC1 $(75 \%)$ and PC2 $(14 \%)$. Red = extreme values of coral recruitment success, blue $=$ extreme values of density dependent mortality for fish and urchins. In (B), 69\% of the total variance is captured by PC1 (51\%) and PC2 (18\%). Green circles = extreme values of sedimentation's scaling factor upon coral mortality. 
Coral

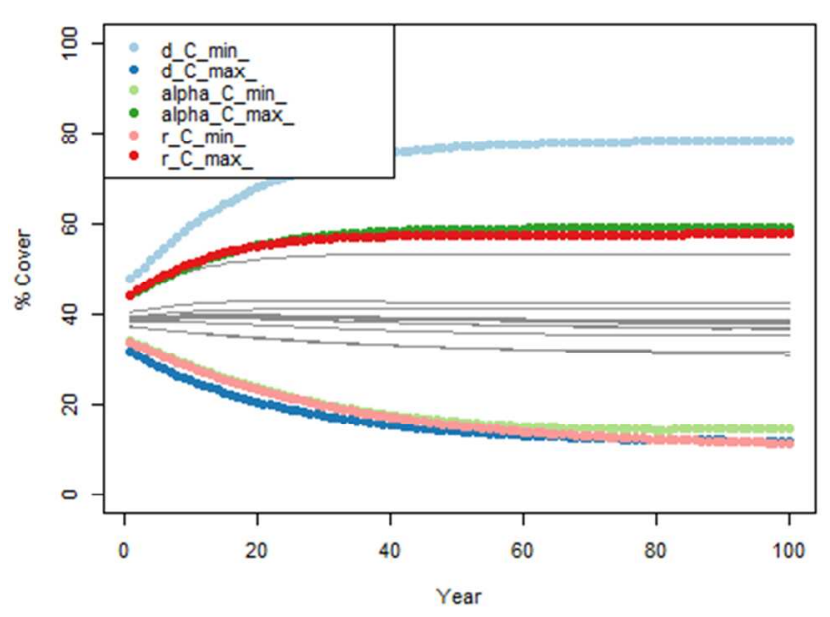

Herbivores

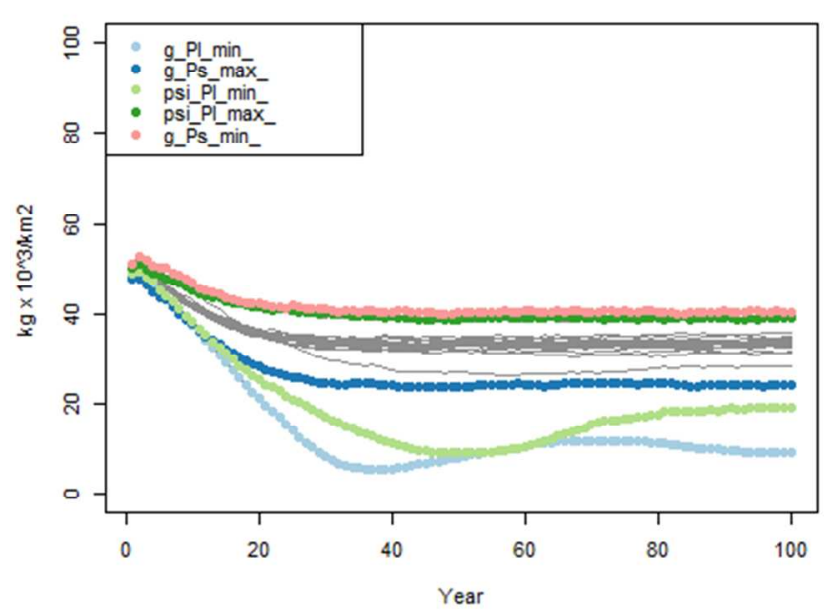

Macroturf

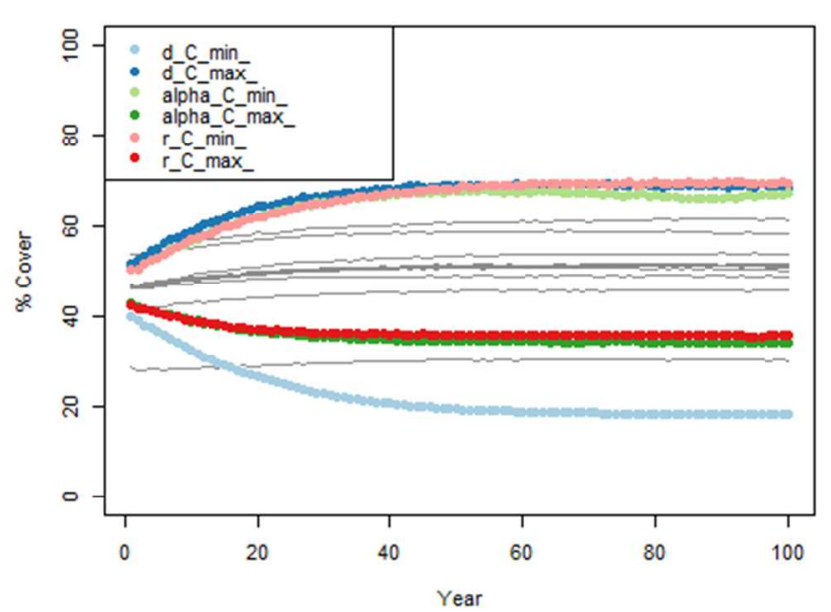

Small Piscivores

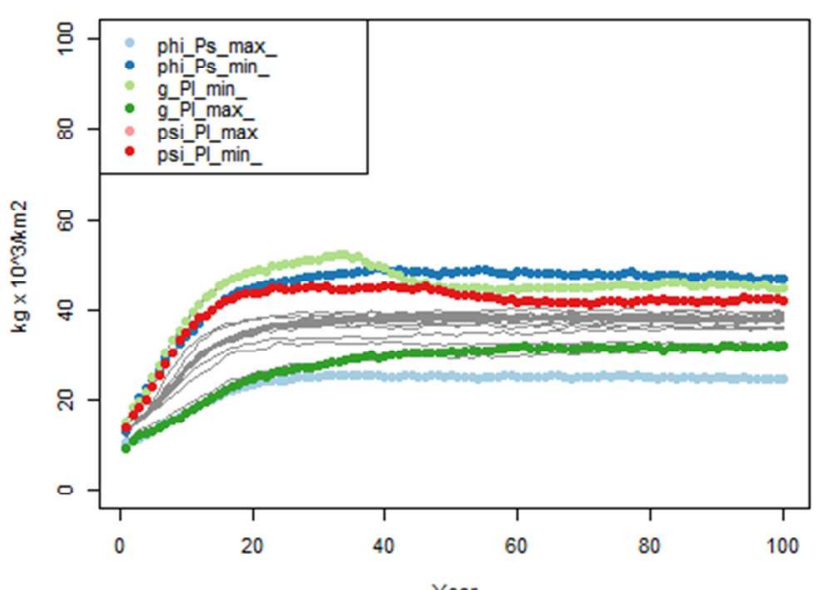

Year
EAC

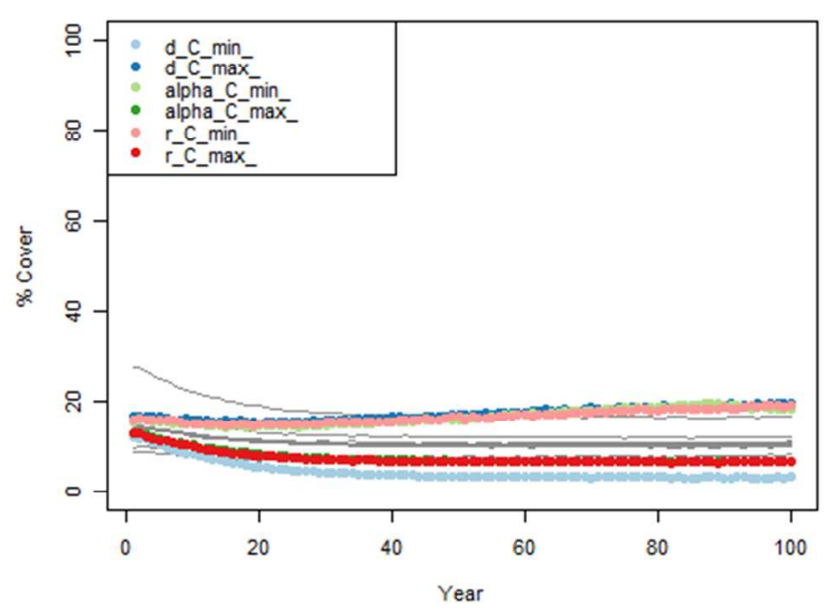

Large Piscivores

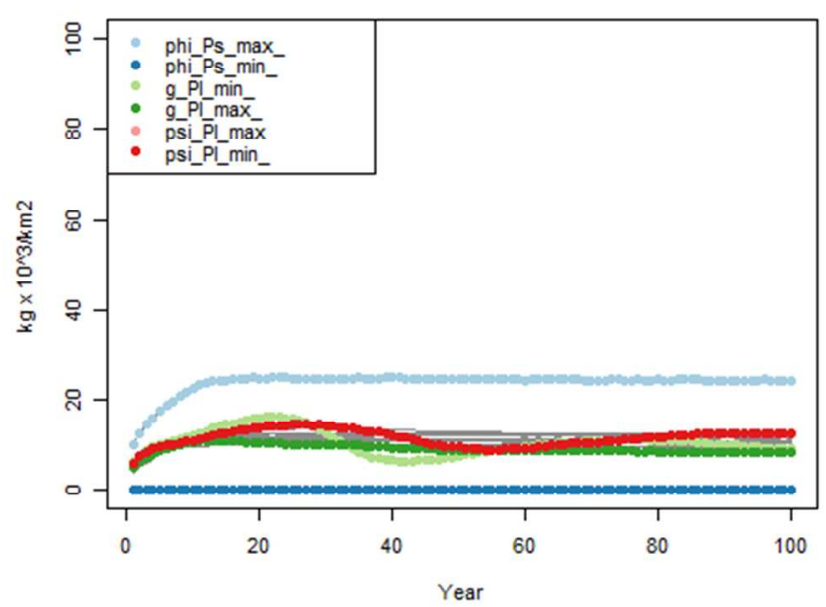

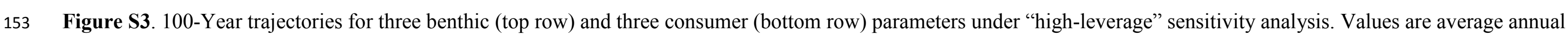

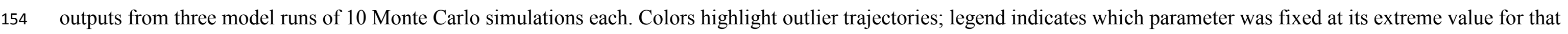




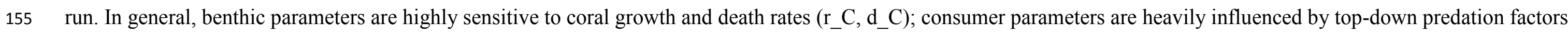

156 (g_Pl, g_Ps) and the growth rate of small piscivores into large (phi_Ps). For complete descriptions and ranges for all parameters, see Appendix. 


\section{Induced Bleaching/recovery trajectories}

We selected the top seven highest-leverage parameters, as indicated by eigenvalue scores from the sensitivity analysis, to evaluate their effect on recovery trajectories following a severe bleaching event at year 55. The outcomes from this examination are summarized in Table S3. Reef state recovered under high coral growth rates, fecundity and low coral mortality. It also recovered to its original state at both the minimum and maximum values of small piscivore graduation rate, and the density dependent mortality for fish in urchins, suggesting that these two parameters are less central to benthic regimes shifts. High coral mortality, low coral growth and fecundity rates and high piscivore biomass each induced a phase shift to an algal-dominated state. The MHI instantiation did not capture neither parameters relevant to the accessibility of algae to sea urchin nor herbivorous fish grazing as high-leverage, though they were found to be so in Meso-America. Instead, two new parameters regarding predation and growth of piscivores

\begin{tabular}{|c|c|c|c|}
\hline Benthic Parameters & & minimum & maximum \\
\hline Coral death rate & d_C & $\bullet$ & $\mathbf{\Delta}$ \\
\hline Coral growth rate over macroturf & alpha_C & $\Delta$ & $\bullet$ \\
\hline Coral growth rate & r_C & $\Delta$ & $\bullet$ \\
\hline \multicolumn{4}{|l|}{ Consumer Parameters } \\
\hline $\begin{array}{l}\text { Proportion of small-to-intermediate piscivorous fish biomass that } \\
\text { becomes large piscivorous fish biomass due to predation and } \\
\text { subsequent growth }\end{array}$ & phi_Ps* & $\bullet$ & $\bullet$ \\
\hline $\begin{array}{l}\text { The maximum predation rate of large piscivorous fish on } \\
\text { herbivorous fish }\end{array}$ & g_Pl* & $\bullet$ & $\bullet$ \\
\hline Death rate of herbivorous fish & d_H & $\bullet$ & $\bullet$ \\
\hline Death rate of small-to-intermediate piscivores & d_Ps & $\Delta$ & $\bullet$ \\
\hline Death rate of large piscivores & d_Pl & $\Delta$ & $\bullet$ \\
\hline \multicolumn{4}{|l|}{ Larval Parameters } \\
\hline Brooding coral fecundity & $\begin{array}{l}\text { dlarv_C } \\
\mathrm{b}\end{array}$ & $\bar{\Delta}$ & $\bullet$ \\
\hline Density dependent mortality rate for fish and urchins & drec_C & • & $\bullet$ \\
\hline
\end{tabular}


are deemed important in this region.

Table S3. Recovery responses for severe bleaching event under extreme values of high-leverage parameters. A triangle $(\boldsymbol{\Delta})$ indicates the community underwent a coral-algal phase shift; a circle $(\bullet)$ indicates the community recovered to its previous state. Starred values were novel to this instantiation and were not identified as high-leverage in the Meso-American system.

\section{Additional figures from the Model Validation}
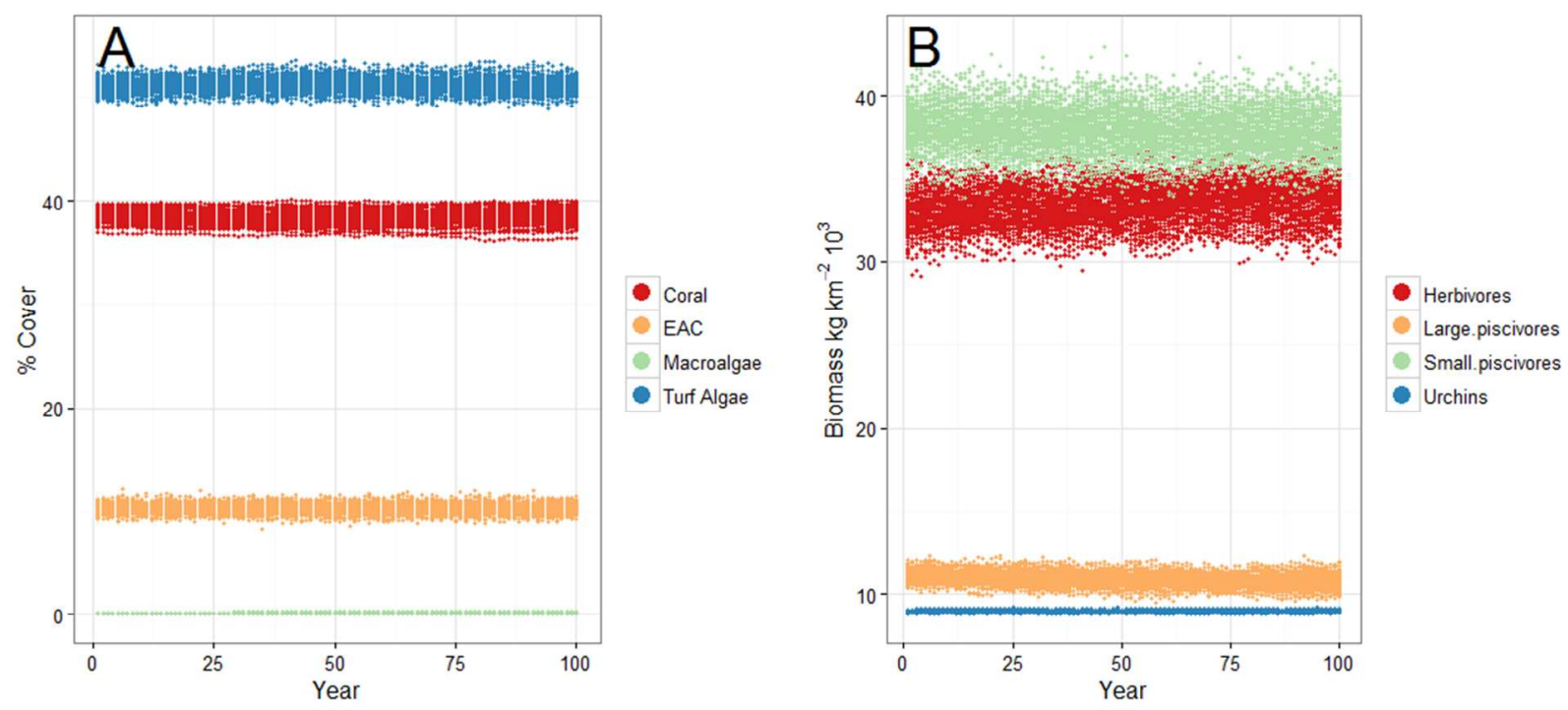

Figure S4A,B. Model trajectories for benthic and consumer variables, year $0-100$, from 100 Monte Carlo simulations. With no forcings. CORSET demonstrates stable-state dynamics after $\sim 30$ years. 

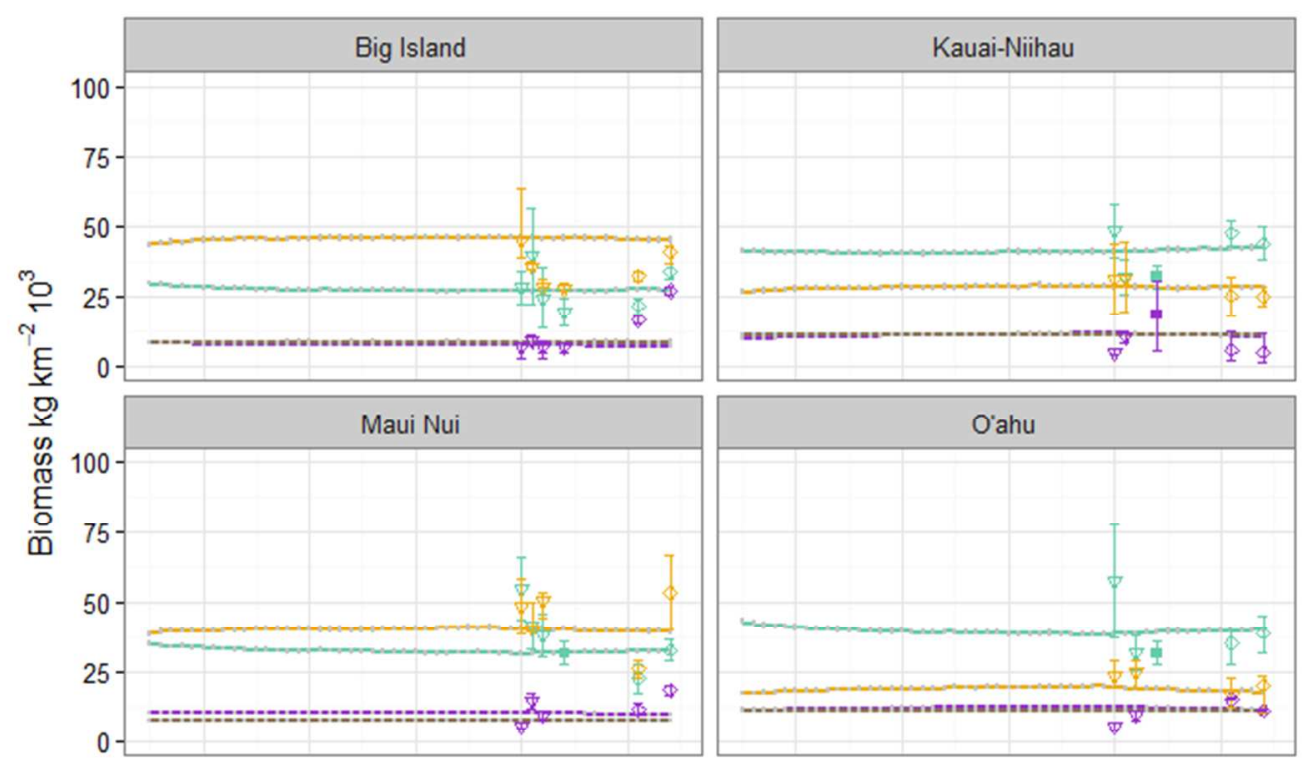

- Coyne et al. (2013)

$\diamond$ NOAA, unpubl.

$\nabla$ Rodgers et al. (2010)

- Rodgers et al. (2015)

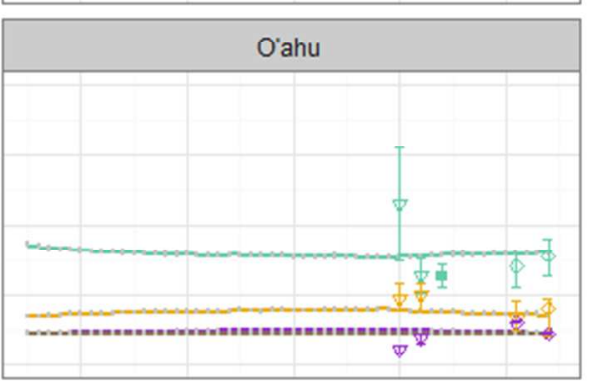

$\rightarrow$ Herbivores

- Large Piscivores

$\rightarrow$ Small Piscivores

$\rightarrow$ Urchins
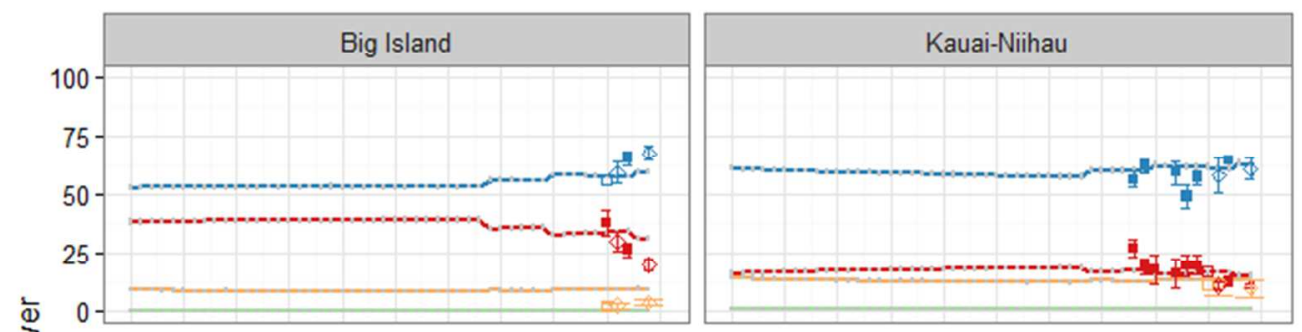

ठ

1

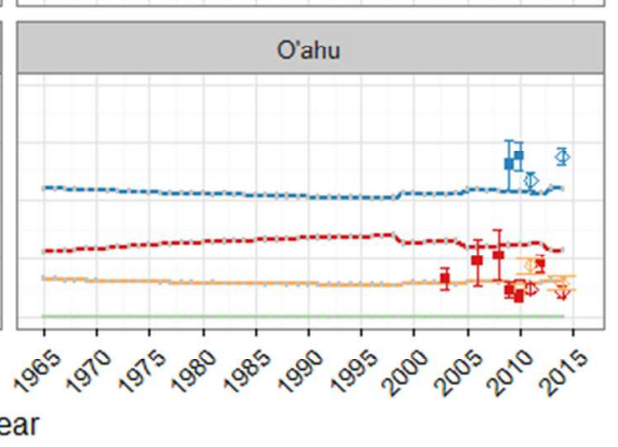

口 Coyne et al. (2013)

$\diamond$ NOAA, unpubl.

$\nabla$ Rodgers et al. (2010)

- Rodgers et al. (2015)

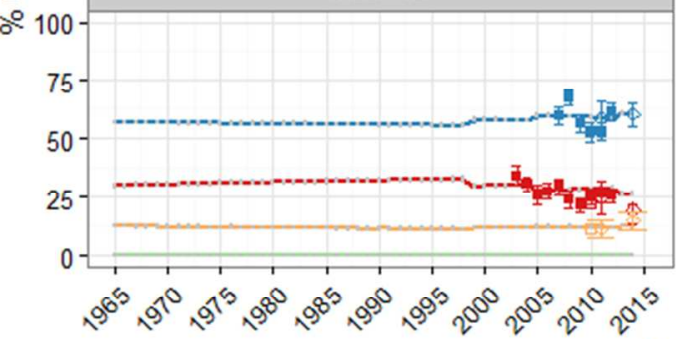

Year

$\rightarrow$ Coral

$\rightarrow$ EAC

$\rightarrow$ Macroalgae

$\sim$ Turf Algae

2 Figure S5. Subregional model trajectories for consumer (upper) and benthic (lower) parameters

3 from 1965 to present from 100 Monte Carlo simulations. Dashed lines represent 95\% confidence

4 intervals for each year. 

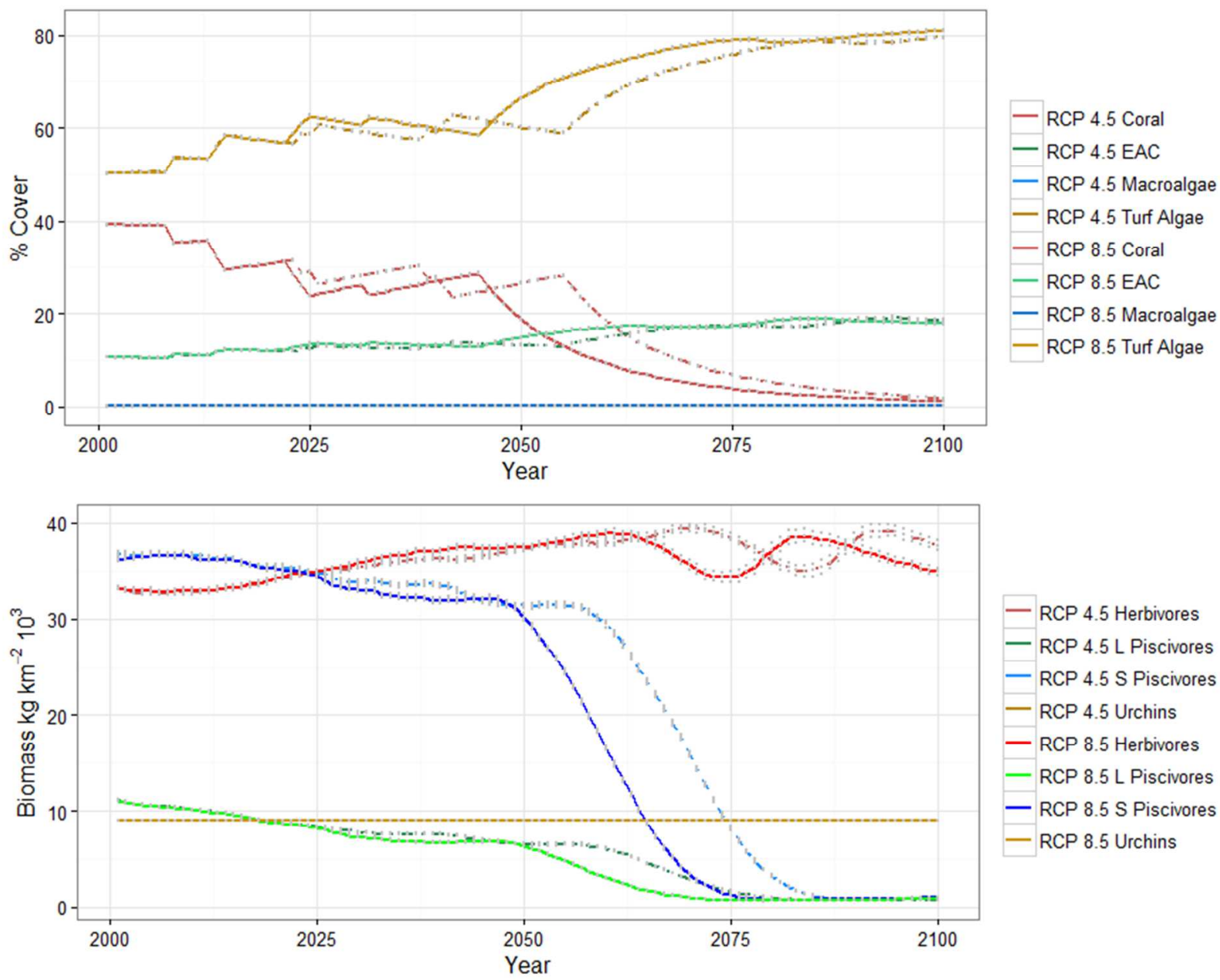

RCP 4.5 Herbivores

- RCP 4.5 L Piscivores

- RCP 4.5 S Piscivores

- RCP 4.5 Urchins

- RCP 8.5 Herbivores

- RCP 8.5 L Piscivores

- RCP 8.5 S Piscivores

— RCP 8.5 Urchins

Figure S6. Modeled 100-year trajectories from 100 Monte Carlo simulations following RCPs 4.5 (dashed lines) and 8.5 (solid lines). Scenario Sweep: RCP 4.5 vs. RCP 8.5

For comparative purposes, we examined model trajectories across all state variables for two proposed emissions-mitigation scenarios, Representative Concentration Pathways 4.5

11 (mitigation) and 8.5 (business as usual, (Riahi et al. 2011). Both model runs were parameterized

12 equally, with the exception that bleaching in RCP 4.5 occurs with a long-term, randomly

13 generated frequency of twice per decade (Hoeke et al. 2011), which transitions to annually in

14 year 2056; the same applies to RCP 8.5 with the transition occurring sooner, in 2056 (Van 
15 Hooidonk et al. 2014). RCP 8.5 is unilaterally worse-off than the mitigations scenario; with

16 high-trophic fisheries collapsing along with the coral community at large; the latter occurs to a

17 lesser degree and later in RCP 4.5.

18
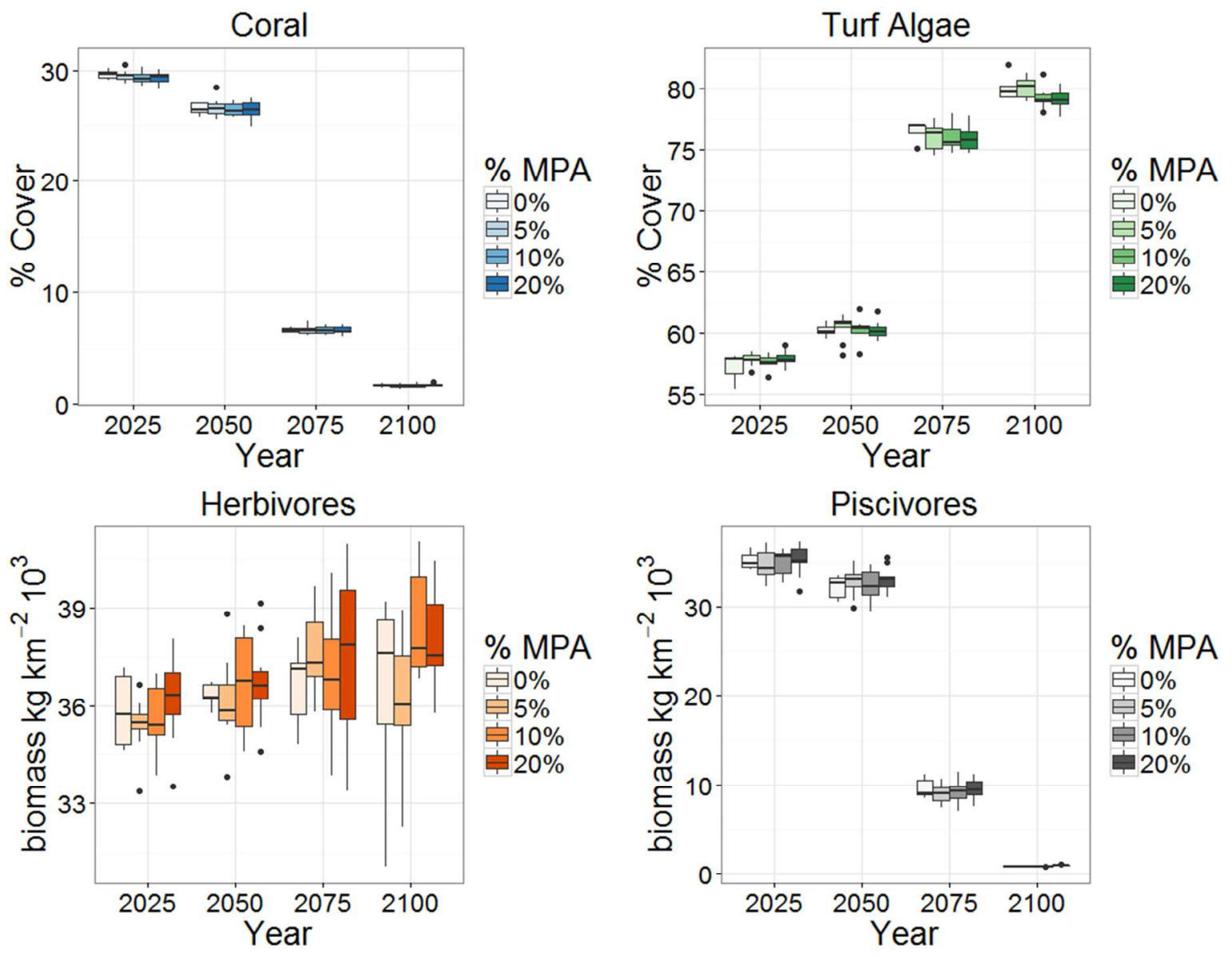

Figure S7. Modeled state variable responses for four marine protected area scenarios under

21 RCP 4.5. Each panel represents a single response variable; individual boxes are color-coded by

22 the percentage of reef cells closed to fishing activity. 


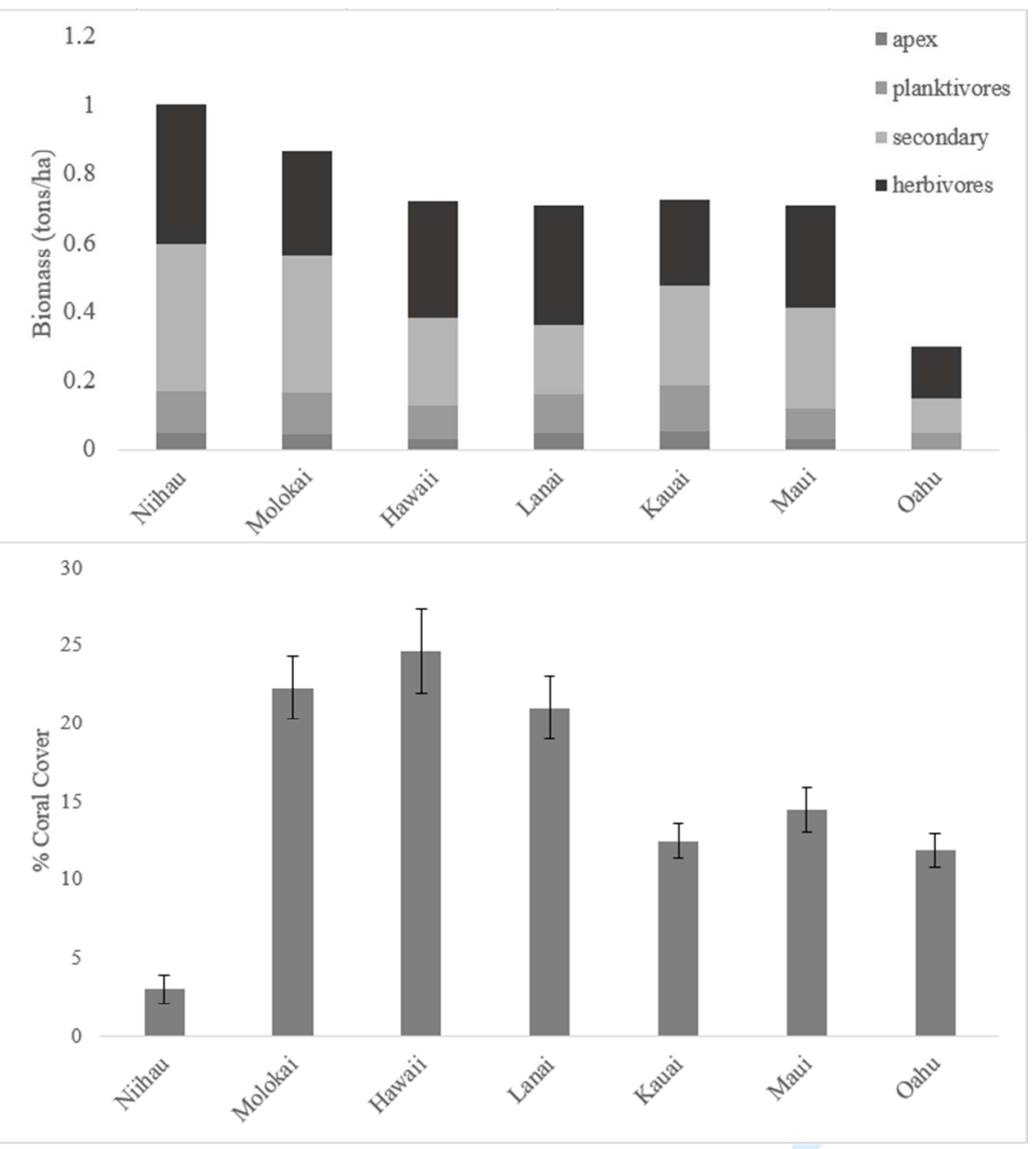

Figure S8A,B. A) Fish biomass by island, in tons/hectare. B) Percent coral cover by island. Data from (Rodgers et al. 2015), representing mean values for years 2001-2008. 


\section{Additional Summary Tables \& Figures for the Scenario Sweep}

Scenario Name

RCP 4.5

RCP 8.5
RCP 8.5 + ntMPAs
RCP 8.5 + Nutrification

Between zero and $2 x$ the mean

reported value for the subregion

reported value for the subregion

reported value for the subregion

Bero and $2 x$ the mean

$5 \%, 10 \%$, and $20 \%$ of reef cells

completely closed to fishing take

for model run

Bleaching occurs in years 2009, Bleaching occurs in years 2009

2014 and 2015 followed by a 2014 and 2015 followed by a

long-term frequency of twice long-term frequency of twice per

per decade until year 2046, after decade until year 2046, after

which it occurs annually;

mortality ranges from $0.05-$

0.15

which it occurs annually;

mortality ranges from $0.05-$

0.15 .

annually; mortality ranges from 0.05 $-0.15$

No modeled forcing

No modeled forcing
Bleaching occurs in years 2009, 2014 and 2015 followed by a long-term frequency of twice per decade until year 2046, after which it occurs annually; mortality ranges from 0.05 0.15 .

At each of $5 \%, 10 \%$, and $20 \%$ proportion of reef cells are designated as "affected by nutrification"; the scaling factor for turf algae growth rate is $2-7$; the scaling factor for coral larval production is $0.75-1.0$
Bleaching occurs in years 2009 , 2014 and 2015 followed by a longterm frequency of twice per decade until year 2046, after which it occurs annually; mortality ranges from 0.05 -0.15 .
RCP 8.5 + ntMPAs +

\section{Nutrification}

Between zero and $2 \mathrm{x}$ the mean

reported value for the subregion; $5 \%$, $10 \%$, and $20 \%$ of reef cells completely closed to fishing take for model run

At each of $5 \%, 10 \%$, and $20 \%$

MPAs, an equivalent proportion (yet not the same cells) are designated as "affected by nutrification"; the scaling factor for turf algae growth rate is $2-7$; the scaling factor for coral larval production is $0.75-1.0$

28 Table S4. Details of forcing conditions used in the scenario sweep. 
High Nutrification (20\%)

\begin{tabular}{|c|c|c|}
\hline Coral cover $(\%)$ & $\begin{array}{l}\text { Nears collapse after } 2075 \text { : } \\
\text { generally higher than scenarios with } \\
\text { more nutrification }\end{array}$ & $\begin{array}{l}\text { Nears collapse after } 2075 \text {; consistently } \\
\text { lower than scenarios with less } \\
\text { nutrification }\end{array}$ \\
\hline Turf algae cover (\%) & $\begin{array}{l}\text { Increases over time; consistently } \\
\text { higher than scenarios with more } \\
\text { nutrification }\end{array}$ & $\begin{array}{l}\text { Increases over time; consistently lower } \\
\text { than scenarios with less nutrification }\end{array}$ \\
\hline Macro algae cover (\%) & $\begin{array}{l}\text { Increases over time; consistently } \\
\text { lower than scenarios with more } \\
\text { nutrification }\end{array}$ & $\begin{array}{l}\text { Increases over time, significantly \& } \\
\text { consistently higher than scenarios with } \\
\text { less nutrification }\end{array}$ \\
\hline $\begin{array}{l}\text { Herbivorous Biomass } \\
(\mathrm{kg} / \mathrm{km} 2)\end{array}$ & Generally stable over time & Generally stable over time \\
\hline $\begin{array}{l}\text { Piscivorous Biomass } \\
(\mathrm{kg} / \mathrm{km} 2)\end{array}$ & $\begin{array}{l}\text { Collapses after } 2050 \text {; consistently } \\
\text { lower than scenarios with more } \\
\text { nutrification }\end{array}$ & $\begin{array}{l}\text { Collapses after 2050; slightly higher } \\
\text { than less-nutrified scenarios }\end{array}$ \\
\hline \multicolumn{3}{|c|}{$\begin{array}{l}\text { TABLE S5. SUMMARY OF STATE VARIABLE RESPONSES TO VARIED NUTRIFICATION REGIMES } \\
\text { WITHIN SCENARIO SWEEP. }\end{array}$} \\
\hline Parameter & $\begin{array}{l}\text { Low no-take MPA + Low } \\
\text { Nutrification }(5 \%)\end{array}$ & $\begin{array}{l}\text { High no-take MPA+ High } \\
\text { Nutrification }(20 \%)\end{array}$ \\
\hline Coral cover $(\%)$ & $\begin{array}{l}\text { Nears collapse after 2075; consistently } \\
\text { higher than more-impacted scenarios }\end{array}$ & $\begin{array}{l}\text { Nears collapse after } 2075 \text {; consistently } \\
\text { lower than less-impacted scenarios }\end{array}$ \\
\hline Turf algae cover (\%) & $\begin{array}{l}\text { Increases over time; indistinguishable } \\
\text { from more-impacted scenarios }\end{array}$ & $\begin{array}{l}\text { Increases over time; indistinguishable } \\
\text { from lesser-impacted scenarios }\end{array}$ \\
\hline Macro algae cover $(\%)$ & $\begin{array}{l}\text { Increases mid-century, then returns to } \\
\text { previous levels }\end{array}$ & $\begin{array}{l}\text { Increases mid-century, then returns to } \\
\text { previous levels }\end{array}$ \\
\hline $\begin{array}{l}\text { Herbivorous Biomass } \\
(\mathrm{kg} / \mathrm{km} 2)\end{array}$ & Generally stable over time & $\begin{array}{l}\text { Generally stable over time; } \\
\text { consistently higher than scenarios with } \\
\text { less protection }\end{array}$ \\
\hline $\begin{array}{l}\text { Piscivorous Biomass } \\
(\mathrm{kg} / \mathrm{km} 2)\end{array}$ & $\begin{array}{l}\text { Nearly collapses after } 2050 \text {; } \\
\text { consistently lower than more- } \\
\text { protected scenarios }\end{array}$ & $\begin{array}{l}\text { Nears collapse after } 2050 \text {; slightly } \\
\text { higher than scenarios with less } \\
\text { protection }\end{array}$ \\
\hline
\end{tabular}

TABLE S6. SUMMARY OF STATE VARIABLE RESPONSES TO PAIRED NO-TAKE MPAS AND NUTRIFICATION REGIMES WITHIN THE SCENARIO SWEEP. 


\section{References - Supplementary Material}

Babcock, R.C., 1985. Growth and mortality in juvenile corals (Goniastrea, Platygyra and Acropora) in the first year. Proceedings of the 5th International Coral Reef Symposium, pp.355-360.

Bell, P.R.F., Lapointe, B.E. \& Elmetri, I., 2007. Reevaluation of ENCORE: support for the eutrophication threshold model for coral reefs. Ambio, 36(5), pp.416-424.

Birrell, C.L., McCook, L.J. \& Willis, B.L., 2005. Effects of algal turfs and sediment on coral settlement. Marine Pollution Bulletin, 51(1-4), pp.408-414.

Bruno, J.F. \& Selig, E.R., 2007. Regional decline of coral cover in the Indo-Pacific: Timing, extent, and subregional comparisons. PLoS ONE, 2(8).

De'ath, G. et al., 2012. From the Cover: The 27-year decline of coral cover on the Great Barrier Reef and its causes. Proceedings of the National Academy of Sciences, 109(44), pp.17995-17999.

Dollar, S.J., 1982. Wave stress and coral community structure in Hawaii. Coral Reefs, 1(2), pp.71-81. Available at: http://dx.doi.org/10.1007/BF00301688.

Dollar, S.J. \& Grigg, R.W., 2004. Anthropogenic and Natural Stresses on Selected Coral Reefs in Hawai'i: A Multidecade Synthesis of Impact and Recovery. Pacific Science, 58(2), pp.281-304. Available at: http://muse.jhu.edu/content/crossref/journals/pacific_science/v058/58.2dollar.pdf.

Dollar, S.J. \& Tribble, G.W., 1993. Recurrent storm disturbance and recovery: a long-term study of coral communities in Hawaii. Coral Reefs, 12(3-4), pp.223-233. Available at: $<$ Go to ISI $>$ ://WOS:A1993ML33800014\nhttp://link.springer.com/content/pdf/10.1007\%2FBF00334481.pdf.

Eble, J. a. et al., 2011. Escaping paradise: Larval export from Hawaii in an indo-pacific reef fish, the yellow tang zebrasoma flavescens. Marine Ecology Progress Series, 428, pp.245-258.

Fung, T., 2009. Local scale models of coral reef ecosystems for scenario testing and decision support.

Fung, T., Seymour, R.M. \& Johnson, C.R., 2011. Alternative stable states and phase shifts in coral reefs under anthropogenic stress E092-082-A3. Ecology, 92(92), pp.967-982.

Gardner, T.A. et al., 2005. Hurricanes and caribbean coral reefs: Impacts, recovery patterns, and role in long-term decline. Ecology, 86, pp.174-184.

Hoeke, R.K. et al., 2011. Projected changes to growth and mortality of Hawaiian corals over the next 100 years. PLOS ONE, 6(3).

Jokiel, P.L. et al., 2004. Hawai'i Coral Reef Assessment and Monitoring Program: Spatial Patterns and Temporal Dynamics in Reef Coral Communities. Pacific Science, 58(2), pp.159-174. Available at: https://www.researchgate.net/publication/29737935_Hawai'i_Coral_Reef_Assessment_and_Monitoring_Prog ram_Spatial_Patterns_and_Temporal_Dynamics_in_Reef_Coral_Communities [Accessed February 25, 2016].

Lapointe, B.E., 1989. Macroalgal production and nutrient relations in oligotrophic areas of Florida Bay. Bulletin of Marine Science, 44(1), pp.312-323.

Lapointe, B.E. \& O’Connell, J., 1989. Nutrient-enhanced growth of Cladophora prolifera in harrington sound, bermuda: Eutrophication of a confined, phosphorus-limited marine ecosystem. Estuarine, Coastal and Shelf Science, 28(4), pp.347-360.

Larned, S.T., 1998. Nitrogen- versus phosphorus-limited growth and sources of nutrients for coral reef macroalgae. Marine Biology, 132(3), pp.409-421.

Melbourne-Thomas, J., Johnson, C.R. \& Fulton, E.A., 2011. Characterizing sensitivity and uncertainty in a multiscale model of a complex coral reef system. Ecological Modelling, 222(18), pp.3320-3334. 
Mumby, P.J. et al., 2006. Fishing, Trophic Cascades, and the Process of Grazing on Coral Reefs. Science, 311(5757), pp.98-101. Available at: http://www.sciencemag.org/content/311/5757/98.full.pdf.

Mumby, P.J. \& Dytham, C., 2006. Metapopulation Dynamics of Hard Corals. In Marine Metapopulations. pp. 157203.

Nugues, M.M. \& Roberts, C.M., 2003. Coral mortality and interaction with algae in relation to sedimentation. In Coral Reefs. pp. 507-516.

Oksanen, J. et al., 2013. Package "vegan.” R package ver. 2.0-8, p.254.

Osborne, K. et al., 2011. Disturbance and the dynamics of coral cover on the Great Barrier Reef (1995-2009). PLoS ONE, 6(3).

Ostrander, G.K. et al., 2000. Rapid transition in the structure of a coral reef community: the effects of coral bleaching and physical disturbance. Proceedings of the National Academy of Sciences of the United States of America, 97(10), pp.5297-5302.

R Development Core Team, R., 2011. R: A Language and Environment for Statistical Computing, Available at: http://www.r-project.org.

Rodgers, K.S. et al., 2015. Over a Decade of Change in Spatial and Temporal Dynamics of Hawaiian Coral Reef Communities. Pacific Science, 69(1), pp.1-13. Available at: http://dx.doi.org/10.2984/69.1.1.

Rodgers, K.S. et al., 2010. Quantifying the condition of Hawaiian coral reefs. AQUATIC CONSERVATIONMARINE AND FRESHWATER ECOSYSTEMS, 20(1), pp.93-105. Available at: http://onlinelibrary.wiley.com/store/10.1002/aqc.1048/asset/1048_ftp.pdf? $\mathrm{v}=1 \& \mathrm{t}=\mathrm{i} 5 \mathrm{~g} 2 \mathrm{xr} 1 \mathrm{o} \& \mathrm{~s}=\mathrm{be} 8 \mathrm{~b} 2 \mathrm{f} 64 \mathrm{f} 7 \mathrm{ef6}$ 5411618ad9718a6e4e532d9c6f7.

Schaffelke, B. \& Klumpp, D., 1997. Growth of germlings of the macroalga Sargassum baccularia (Phaeophyta) is simulated by enhanced nutrients. In 8th International Coral Reef Symposium. pp. 1839-1842.

Shchepetkin, A.F. \& McWilliams, J.C., 2005. The regional oceanic modeling system (ROMS): A split-explicit, freesurface, topography-following-coordinate oceanic model. Ocean Modelling, 9(4), pp.347-404.

Stimson, J. \& Larned, S.T., 2000. Nitrogen efflux from the sediments of a subtropical bay and the potential contribution to macroalgal nutrient requirements. Journal of Experimental Marine Biology and Ecology, 252(2), pp.159-180.

Vroom, P.S. \& Timmers, M.A. V, 2009. Spatial and temporal comparison of algal biodiversity and benthic cover at gardner pinnacles, Northwestern Hawaiian Islands. Journal of Phycology, 45(2), pp.337-347.

Zeller, D. et al., 2006. Reconstruction of coral reef fisheries catches in American Samoa, 1950-2002. In Coral Reefs. pp. 144-152. 